補緅誌, J Jpn Prosthodont Soc, $30:$ 108 127, 1986.

\title{
切歯路傾斜度の顆頭運動に与える影響
}

\author{
第 1 報 矢状切歯路傾斜度
}

\author{
加藤 一誠

\section{A Study on Influence of Inclination of Incisal Path on Condylar Path}

Part 1. Sagittal Inclination of Incisal Path

\author{
Kazumasa Katoh
}

\begin{abstract}
There have been not many experimental studies about the influence of incisal path on condylar path, though it is important to know it in clinic. By changing the sagittal inclination of incisal path, the condylar path was influenced both in distance and in inclination.

When the sagittal inclination of incisal path was smaller than that of condylar path, the distance of the tracing of the kinematic-axis point was longer than that of incisal path. The smaller the inclination angle of the incisal-condylar points line in the sagittal view was, the longer the distance of condylar path was.

The inclination angle of the tracing of the arbitrary condylar points depended on its locational relationship with the specific line that intersects at nearly right angles to the condylar path through the kinematic-axis point. That is, the arbitrary condylar points on the specific line had reproducible inclination angle of condylar tracing equally as that of the kinematic-axis point.

When the inclination angle of incisal path was smaller than that of condylar tracing, the points located in front of the specific line had larger inclination angle, and the points located behind the specific line had smaller inclination angle.
\end{abstract}

Key words: experimental study, kinematic-axis point, inclination of saggital incisal path, distance of saggital condylar path, inclination of saggital condylar path

目次

I. 緒 言

II. 研究方法

1. 測定システム

1）測定システムの概要

2）测定精度

2. 基準平面

3. 被験者

新潟大学大学院歯学研究科柬科補繳学専攻 (指導: 石岡 靖教 授)

Niigata University Graduate School of Dentistry Major in Prosthodontics (Director : Kiyoshi Ishioka) 昭和 60 年 8 月 20 日受付
4. 前方滑走運動の誘導方法と運動開始点

5. 顆頭運動の解析点

III. 結 果

1. 顆頭点の位圈
1）顆頭中央点の位置
2) 全運動軸点の位置

2. 矢状切菌路傾斜度の変化が矢状顆路に与える影 然
1）運動距離
2）矢状顆路傾斜度

IV. 考 察

1. 全運動軸点について 
2. 矢状切歯路傾斜度の変化が矢状顆路に与える影 響

1）運動距離に与える影響

2）矢状顆路傾斜度に与える影響

(1) 矢状顆路傾斜度の変化

（2）矢状顆路傾斜度の再現性

a. 前方滑走運動時の矢状顆路傾斜度の再現 性

b. 臨床との関連

V. 結 論

VI. 付 録

1. 全運動軸点の探索方法

2. 下顎の回転角について

3. 任意の顆頭点における顆路傾斜度差 文献

\section{I. 緒 言}

菌牙の接触滑走運動における下頡の三次元 運動軌 跡 は, 前方指導要素である歯牙指導と後方指導要素である 顆路指導とによって定まっている. 補緅治療や矯正治療 など, 臨床において咬合の再構成, あるいは変更する場 合には, 顆路指導は歯牙指導と同等に重視しなければな らないが, 顆路指導は患者に固有のものであり, 術者が 勝手に変更することはできない，そこで，術者にとって 要求されることは，歯牙指導が顆路指導に対して生理機 能的に調和するように配虑することである.

これまで, 歯牙指導と顆路指導との関保について, $2 つ$ の方向から研究が行われてきた. その 1 つは, 多くの 被験者を測定して歯牙指尊・咬合位と顆路指導 ·顆頭位 との間の基準となるべき平均的関係を研究する方法 ${ }^{1 \sim 3}$ であり，もう1つは，実験的に歯牙指導・咬合位を変化 させたときに顆路指導・顆頭位が受ける影響について研 究する方法 ${ }^{4 \sim 7)}$ である. 著者は後者の立場から研究を行 った.

従来の実験的な研究は, 歯牙指導・咬合位の定まって いる正常有歯䫟者について行われていた，そのため，歯 牙が障害となり, 歯牙指導を変化させる場合にはその変 化の範囲に制限を受けるために，咬合を挙上しなければ ならないなど何らかの工夫が必要とされ，自由に歯牙指 導・咬合位を変化させることができなかった。

著者は上記の問題を避けるために, 固有の蒌牙指導 · 咬合位を失った，いわゆるすれちがい咬合者を被験者と した. これによって, 被験者に滑走運動を行わせるとき
に, 同一の咬合位から, 切歯点において矢状あるいは側 方の切歯路傾斜度を可能なかぎり広い範囲にわたって変 化させることができた. 今回は, 矢状切歯路傾斜度の変 化が顆頭運動軌跡に与える影響について検討した.

その結果, 正常有歯笸者と比較して本研究の被験者で は, 全運動軸点の位置が変化している被験者が多いこと がわかった.このような被験者では, 臨床において平均 的顆頭点による矢状顆路傾斜度の測定をすると誤差を生 じる可能性があるので, 全運動軸点による矢状顆路傾斜 度の測定が好ましいと考えられた。

また, 全運動軸点の運動軌跡についてその運動距離と 運動方向 (矢状顆路傾斜度) について詳しく検討した結 果, 切歯点の運動距離を一定にしたときの顆頭の運動距 離の大きさは, 矢状切歯路傾斜度, 矢状顆路傾斜度, 切 歯点と全運動軸点とを含む平面が基準平面となす角度の 3 者によって主に影響を受けること，また，矢状顆路傾 斜度については, 任意の顆頭点の矢状顆路傾斜度の変化 は, 全運動軸点との位置関係によって決定されることが わかった. さらに, 任意の顆頭点の矢状顆路傾斜度の再 現性について検討し, 特に全運動軸点の矢状顆路傾斜度 の再現性を, 簡便に臨床で利用するための新たな後方基 準点の探索方法を提案した.

\section{II. 研究方法}

1. 測定システム

1) 測定システムの概要

本研究は当教室で開発した半導体位置センサを応用し た非接触型下顎任意点運動測定システム ${ }^{8,9)}$ で行った. 被 験者の下䫑が剛体条件を充たし，下額に固着した 3 個の 測定点の 3 次元運動データも剛体条件を充たした 3 次元 運動を行うことを条件とした.これによって，下頑任意 点の運動を計算によって推定することができる.

測定点には近赤外線発光素子 LED（東芝 TLN104）を 用いた. LED は顔弓上の切歯部と左右顆頭部に位置して おり, 顔弓はシーネを介して下䅡歯列弓に固着した. LED の位置は外方に設置したカメラで非接触に検出し， 受光面にある半導体センサ PSD (浜松テレビ社 S1300) で電気信号に変換した. 図 1 にシステムの構成を示した. 光学系を用いて下䫟運動を測定する場合には，頭部が 動摇することを防ぐために, 被験者の頭部を固定する方 法がとられてきたが, 完全に固定することは不可能であ る.そこで，本システムでは，上䫑歯列にシーネを介し て固着した下顎と同様の測定用顔弓によって, 頭部の動 


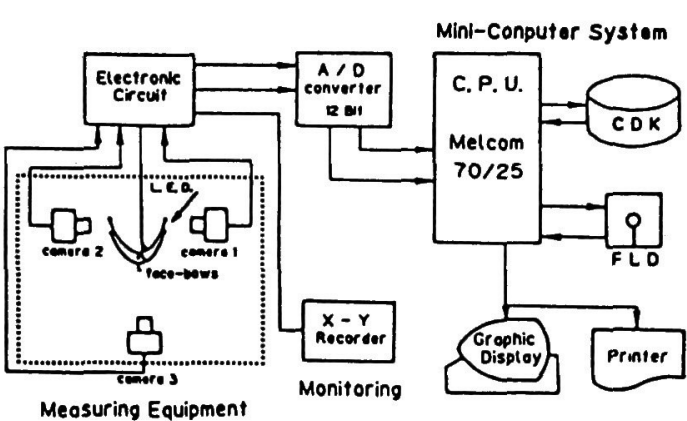

図 1 システム構成

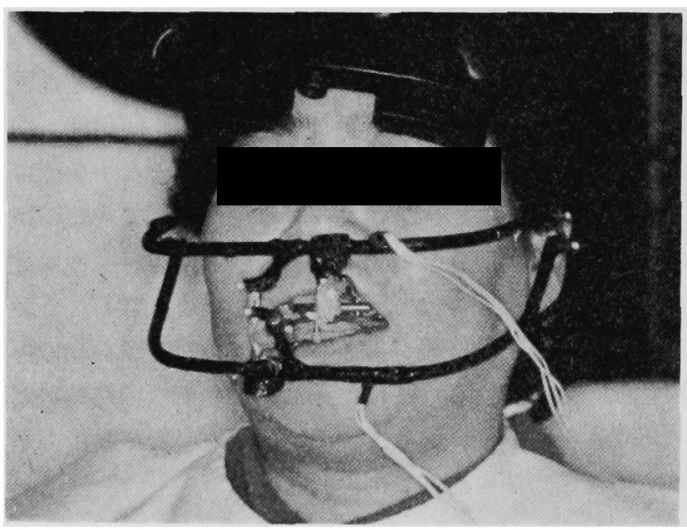

図 2 非接触型下䝷任意点運動測定装置の装着状態

摇も同時に測定した. ただし，LED が光学系の視野から 外れることを防ぐために，下頡運動に支障のない程度に 頭部の固定を前頭部で行った (図 2)、頭部の動摇を伴っ

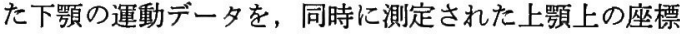

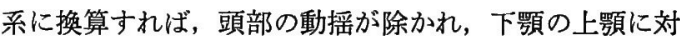
する運動のみ得ることができる.

2）測定精度

測定精度については, 表 1 に LED 座標の測定精度を 示した．位置変化の分解能は, ノイズや顔弓の振動のた めに, $0.15 \mathrm{~mm}$ 以下の識別は不可能であった。 なお，運 動測定におけるサンプル周期は $10 \mathrm{~ms}$ である.

\section{2. 基準平面}

左右の平均的顆頭点と左側鼻翼下縁とで決をる平面を 水平基準平面とした. 平均的顆頭点の位置 ${ }^{10}$ は, 耳珠後縁 と外眼角とを結ぶ線上で $13 \mathrm{~mm}$ 前方の点とした (図 3).

\section{3. 被験者}

被験者は新潟大学歯学部付属病院補緅科敒製作され た部分床義歯を装着している 45〜72 歳の男女 11 名であ
表 1 測定装置の測定精度

\begin{tabular}{cccc}
\hline \hline 顔 弓 & 測 定 領 域 & 座標測定誤差 \\
\hline 上 & 類 & $12 \times 12 \times 12 \mathrm{~mm}^{3}$ & $<0.09 \mathrm{~mm} *$ \\
\hline \multirow{2}{*}{ 下 䪽 } & $20 \times 20 \times 20 \mathrm{~mm}^{3}$ & $<0.12 \mathrm{~mm} *$ \\
& $40 \times 40 \times 40 \mathrm{~mm}^{3}$ & $<0.24 \mathrm{~mm} *$
\end{tabular}

*測定領域内の立方格子点 125 点における最大誤差, ただしノイズの影響は除く

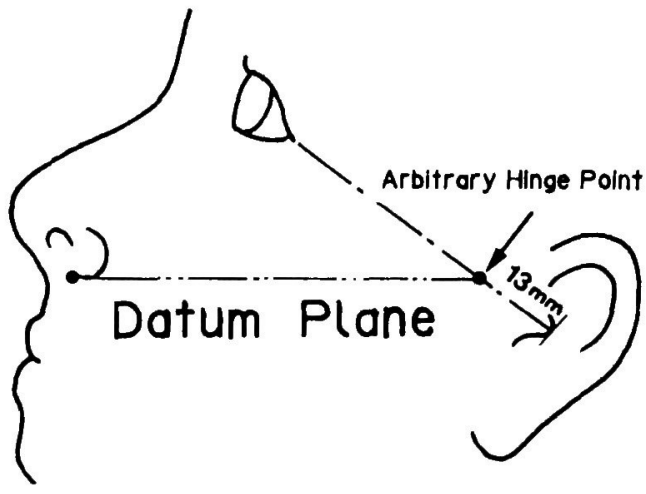

図 3 基淮平面

る. 瀕位は安定しており，顎口腔系機能には臨床的に異 常は認められなかった．残存歯の状態や特記事項など被 験者についての詳細は表 2 に示した。

\section{4. 前方滑走運動の誘道方法と運動開始点}

図 4 に示すように, 前方滑走運動の誘導は, 切歯点で 行った. 被験者の上䫑前歯の欠損部あるいは根面板上で 中切歯舌面相当部に，金属性のガイドグルーブ付ブロッ クを取り付け，下頡中切歯切縁相当部にガイドピンを固 着した.この装置により被験者は前方滑走運動の開始点 から，ピンをガイドグルーブにそわせて常に正中矢状力 向に直線的に前方滑走運動を行うことができた（図 5). ただし，ガイドピンやガイドブロックを固着した歯牙の 動摇が, 測定用顔弓に伝わらないように，誘道装置と測 定装置は分離して歯牙に固着されている.

矢状切歯路傾斜度の変化は, ガイドブロックの交換に よって行った (図 6). 矢状切歯路傾斜度の変化は，前述 の水平基準面（ほぼカンペル氏平面に近い）を $0^{\circ}$ とす ると, $0^{\circ}$ から下方へ $60^{\circ}$ までの範囲を $10^{\circ}$ 間隔で与え た．また，ガイドブロックを交換しても前方滑走運動の 開始点の位置が変化しないように，ガイドブロックの設 計に配慮した。

滑走運動の開始点となる顥位は中心位を採用した，水 
表 2 被 験 者

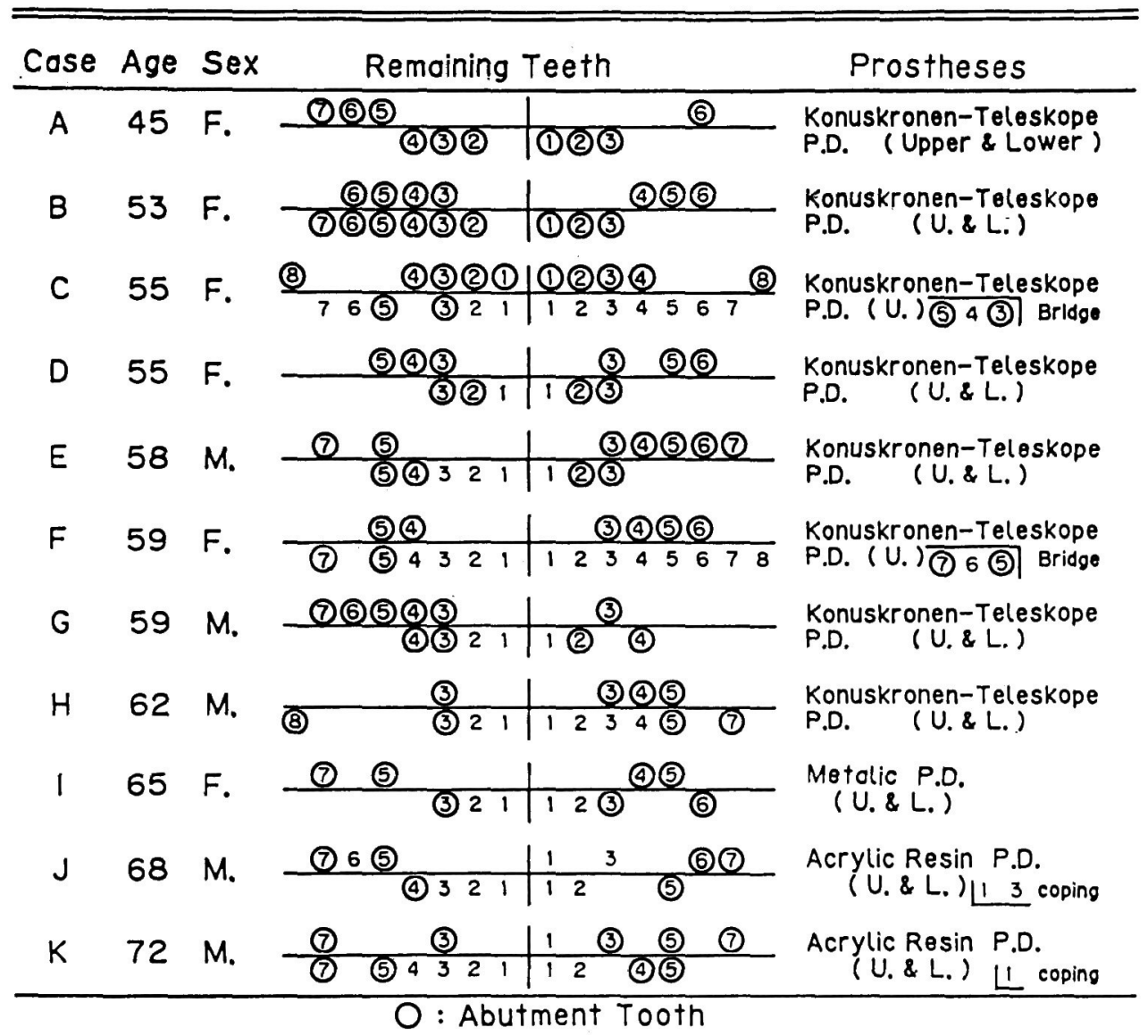

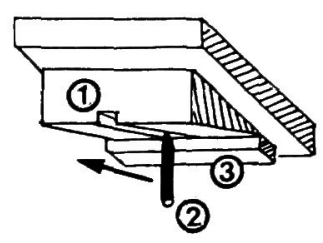

(1) Guide Groove

(2) Guide $P$ in

(3) Stopper

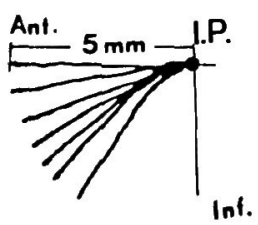

図 4 前方滑走運動の誘導

平的にはゴシックアーチのアペックスに一致しており， 垂直的には接着している義歯の咬合高径に一致してい た. 被験者が現在装着している部分床義歯は, 中心位に て咬合採得して製作した. 被験者は習慣的開閉口運動を

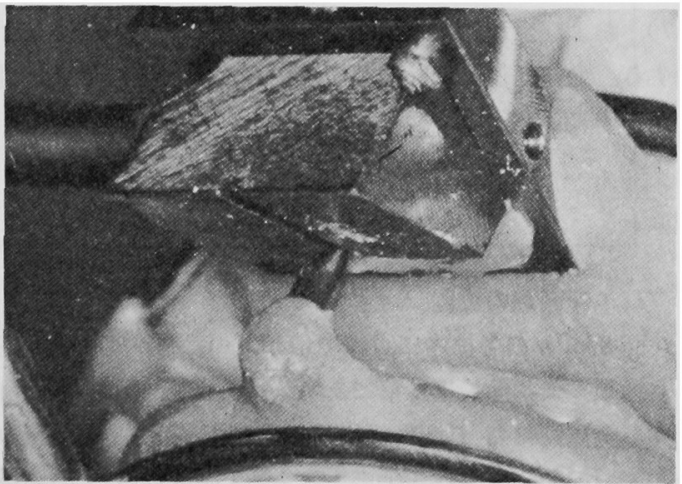

図 5 ガイドグルーブとガイドピン

するときにも，安定してこの顎位を再現することができ た. 


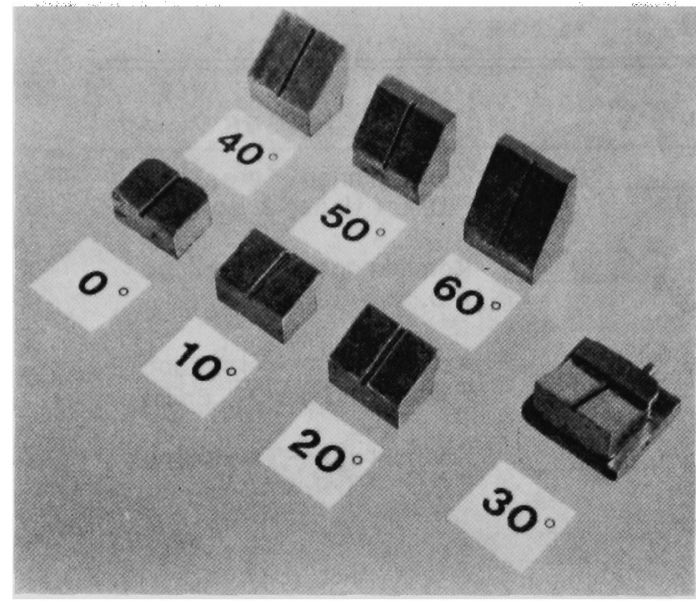

図 6 ガイドブロック

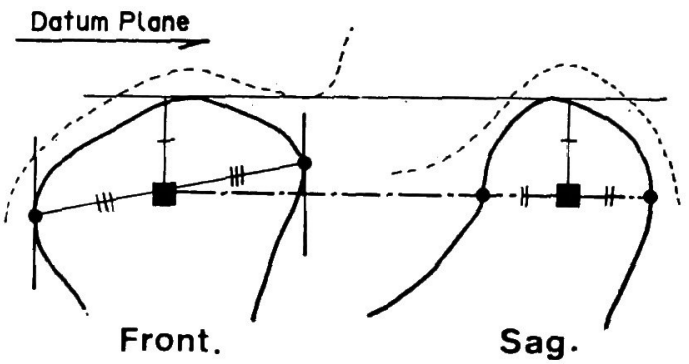

図 7 顆頭中央点の決め方

\section{5. 顆頭運動の解析点}

解剖学的顆頭中央点 (以下顆頭中央点とする. 形態的 な中央点で, 頭部X線規格写真により決定する. 図 3 , 7), および全運動軸上の顆頭中央点（以下全運動軸点と する. 全運動軸上で, 前頭面からみたときの形態的な顆 頭の中央となる点) である.

\section{III. 結 果}

\section{1. 顆頭点の位置}

図 8-a, b の各枠内に点線で示したのは, 各被験者の左 右顆頭の矢状面投影外形である，黒丸が顆頭中央点，白 丸が全運動軸点, 三角印が平均的顆頭点である.横縞線の 領域が，矢状面限界運動をしたときの顆路の上下の幅が $0.7 \mathrm{~mm}^{1)}$ 以下となる顆頭点の領域である. 全運動軸点の 軌跡の上下幅が最小でも $0.7 \mathrm{~mm}$ 以上となる Case I, K では，目視によって上下幅が最も小さく，変化の少ない 軌跡を描く顆頭点の領域とした．全運動軸点はこれらの 領域内で, 最も軦跡の上下幅が小さくなる点である. な
30 巻 1 号 (1986)

お，枠外に全運動軸点の軌跡の上下幅の範囲を示した．

\section{1）顆頭中央点の位置}

前方および後方の解剖学的な各基準点の位 置（図 3) に小鉛玉を付着して，正面および側面の頭部 X線規格写 真を撮影し，X線写真上で作図によって形態的に顆頭の 中央点の位置を決定した（図 7).

その結果, 被験者 11 名 22 顆頭において, 顆頭中央点 の位置は矢状面投影では, 平均的顆頭点から後方へ平均 で $1.0 \mathrm{~mm}$ (最大で $3.8 \mathrm{~mm}$, 最小で $0.0 \mathrm{~mm}$ ), 下方に 平均で $1.1 \mathrm{~mm}$ (最大で $3.8 \mathrm{~mm}$, 最小で $0.0 \mathrm{~mm}$ ) で あった. 距離で示すと $3.7 \pm 2.1 \mathrm{~mm}$ (最大で $7.4 \mathrm{~mm}$, 最小で $0.4 \mathrm{~mm}$ )であった.

前頭面投影では，顆頭中央点の位置は平均的顆頭点か ら内方に $21.9 \pm 3.0 \mathrm{~mm}$ (最大で $29.1 \mathrm{~mm}$ ，最小で 18.2 $\mathrm{mm}$ )であった.

2）全運動軸点の位置

付録 1 に示す探索法 ${ }^{11)}$ により，全運動軸点の位置を決 定した．なお，全運動軸点を探索したときに，各被験者 に与えた矢状切歯路傾斜度は，本研究で与えた矢状切歯 路傾斜度の変化の中央値の $30^{\circ}$ とした.

その結果, 平均的顆頭点からの全運動軸点の位置は, 前方に平均で $1.4 \mathrm{~mm}$ (最大で前方に $7.1 \mathrm{~mm}$, 最小で後 方に $0.4 \mathrm{~mm}$ ), 上方に $6.9 \mathrm{~mm}$ (最大で上方に $18.0 \mathrm{~mm}$, 最小で下方に $0.7 \mathrm{~mm}$ ) であった. 距離で示すと $7.8 \pm$ $4.9 \mathrm{~mm}$ (最大で $19.0 \mathrm{~mm}$, 最小で $1.0 \mathrm{~mm}$ )であった.

顆頭中央点からの位置では，前方に $0.5 \mathrm{~mm}$ （最大で 前方に $5.0 \mathrm{~mm}$ ，最小で上方に $0.3 \mathrm{~mm}$ ), 上方に $8.7 \mathrm{~mm}$ （最大で上方に $18.4 \mathrm{~mm}$, 最小で下方に $0.7 \mathrm{~mm}$ ) であっ た. 距離で示すと, $10.0 \pm 4.9 \mathrm{~mm}$ (最大で $18.4 \mathrm{~mm}$, 最 小で $1.3 \mathrm{~mm}$ ) であった.

図 9 注各被験者に矢状面の限界運動を行わせたときの 両顆頭点の運動軌跡である．なお，各被験者の全運動軸 点の運動軌跡の上下幅は最小で $0.41 \mathrm{~mm}$ ，最大で 0.92 $\mathrm{mm}$, 平均で $0.61 \pm 0.18 \mathrm{~mm}$ であった. 特に, Case A, I $\mathrm{K}$, では值が大きく $0.75 \sim 0.92 \mathrm{~mm}$ となった.

2. 矢状切歯路傾斜度の変化が矢状顆路に与える影響 前方滑走運動時の矢状切歯路傾斜度の変化が，顆頭運 動軌跡に与える影響を解析した．解析項目は，顆頭中央 点と全運動軸点との軌跡の運動距離と運動方向（矢状顆 路傾斜度）である．切歯点の運動距離は $5 \mathrm{~mm}$ に規格化 した.

1) 運動距離

図 10 に各矢状切歯路傾斜度に対する，各被験者の顆 
Case A

Case D

Post. Right Ant. Ant. Left Post.

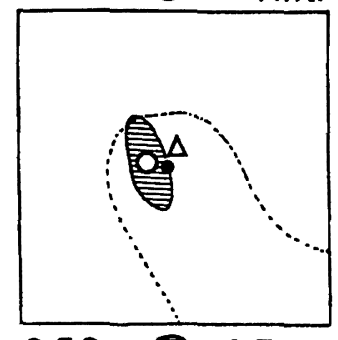

$0.56 m \leq \theta \leq 0.70 m$
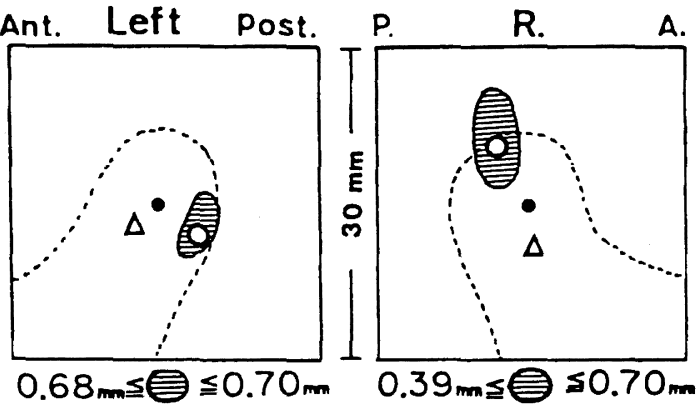

A. A.

L.

P.

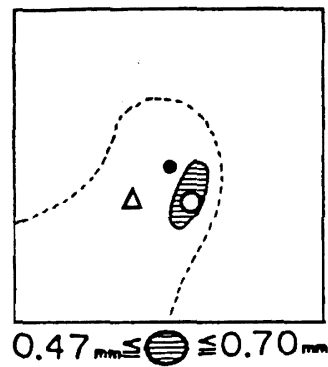

Case B

Case $E$

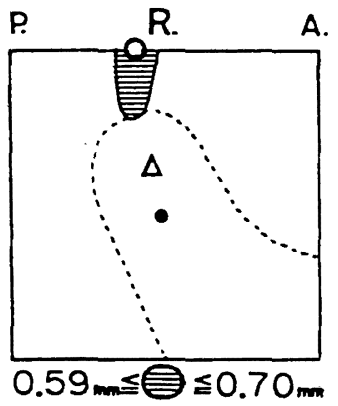

A. A.

L.

P. $P$

R.

A. A.

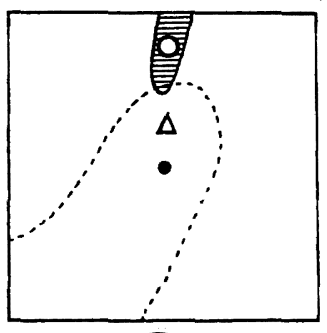

$0.43 \mathrm{~m} \leqq 0.70 \mathrm{~mm}$
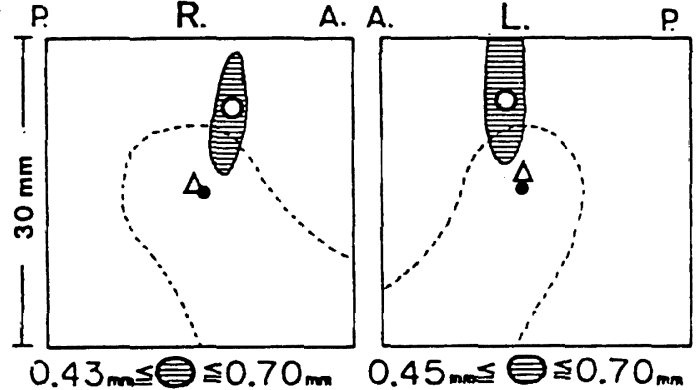

Case C

$0.43 \mathrm{~m} \leq \theta \leq 0.70 \mathrm{~m}$

$0.45 \mathrm{ma} \theta \leq 0.70_{\mathrm{mm}}$
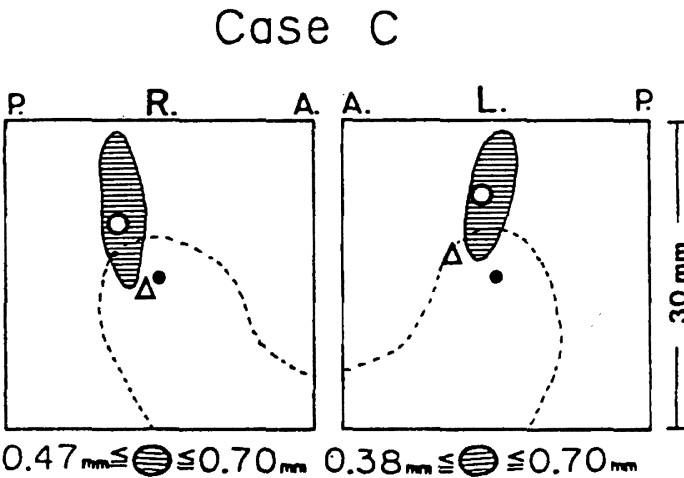

$0.38 \mathrm{~mm} \leqq 0.70 \mathrm{~mm}$
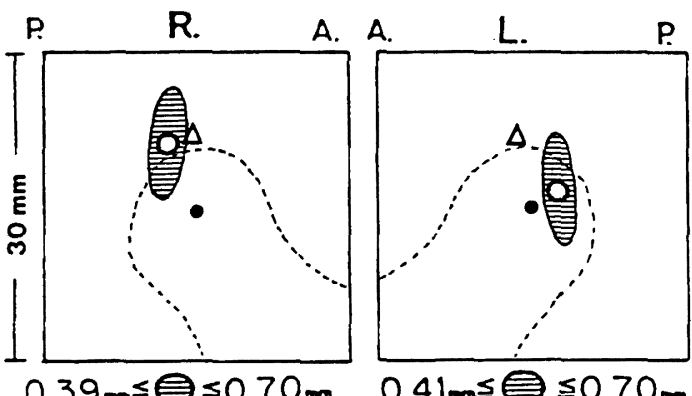

$0.41 \mathrm{~mm} \fallingdotseq \leqq 0.70 \mathrm{~mm}$

図 8- a 全運動軸点, 顆頭中央点, 平均的顆頭点の位置

頭中央点の運動距離を示す。横軸が矢状切歯路傾斜度,

縦軸が被験者 11 名 22 顆頭における顆頭中央点の運動距

離である.なお，全運動軸点については図 11 にまとめ て示す.

図 11 には顆頭中央点と全運動軸点との運動距離の平 均値を示す. 黒丸は顆頭中央点, 白丸は全運動軸点であ る. ( ) 内の数值は, 切歯点の運動距離 $5 \mathrm{~mm}$ を基準 としたときに, 各矢状切歯路傾斜度に対する両顆頭点の
運動距離を百分率で表したものである.下の棒グラフは それぞれの分散を示している.

その結果, 顆頭中央点の運動距離は, 矢状切歯路傾斜 度の変化 $\left(0^{\circ} \sim 60^{\circ}\right)$ の影響を受けた. 11 名 22 顆頭の運 動距離の平均值は矢状切歯路傾斜度の約 $0^{\circ} \sim 10^{\circ}$ の範囲 で渐增し，約 $10^{\circ}$ から淵減した. $0^{\circ}$ のときで $4.96 \pm 0.43$ $\mathrm{mm}$ (切歯点の運動距離の約 $98 \%$ ), $10^{\circ} \sim 20^{\circ}$ の籁囲で $5.05 \pm 0.32 \mathrm{~mm}$ (約 $101 \%$ ), 約 $30^{\circ}$ 以上で漸減し， $55^{\circ}$ 
Case G

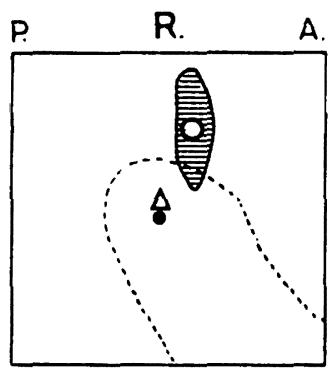

$0.38 \mathrm{~mm} \cong 0.70 \mathrm{~mm} 0.43 \mathrm{~mm} \triangleq 0.70 \mathrm{~mm}$

\section{Case $H$}

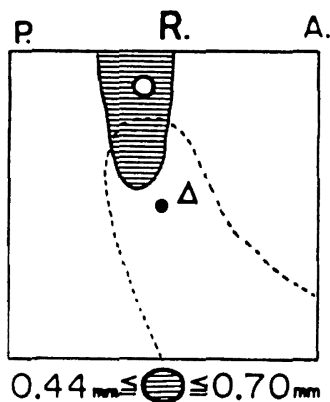

A. A.

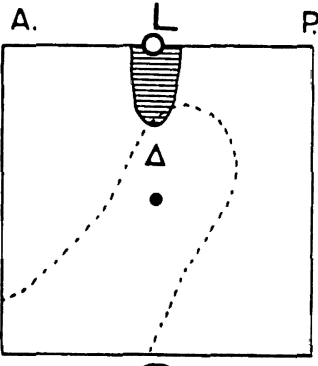

$0.38 \mathrm{~m} \leq 0.70 \mathrm{~m}$
Case J

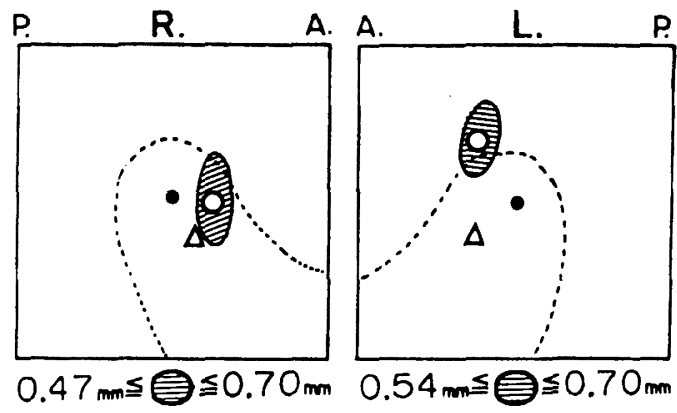

Case $K$

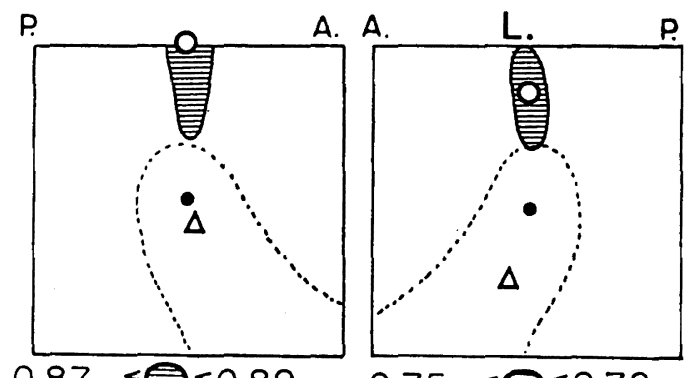

Case 1

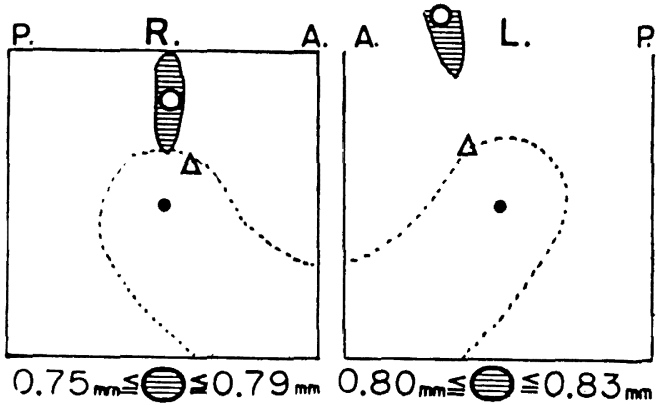

: Kinematic Axis Point Area

$\theta:$ The Difference between Maximum \& Minimum Inclination of the Condylor Poth

0 : Kinematic Axis Point

- : Central Point of Condyle

$\Delta:$ Arbitrary Condylar Point

図 8-b 全運動軸点, 顆頭中央点, 平均的顆頭点の位苗

で最小值 $4.04 \pm 0.57 \mathrm{~mm}$ (約 $80 \%$ ）となった. なお,

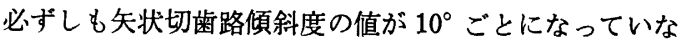
いのは, 誘導装置の設定位置の誤差と, ガイドピンを個 着した歯牙の動摇による．ただし，測定装置は諉導装置 と分離して装着されているので，誘導装置の動摇は測定 装置に伝わらない.

全運動軸点の運動距離も矢状切歯路傾斜度の影響を受
けた. 矢状切歯路傾斜度の約 $0^{\circ} \sim 20^{\circ}$ の範囲で漸増し， 約 $30^{\circ}$ から漸減した. 矢状切歯路傾斜度が約 $0^{\circ}$ のとき で $4.77 \pm 0.35 \mathrm{~mm}$ (約 $95 \%$ ), $20^{\circ} \sim 30^{\circ}$ の籁囲で 5.04 $\pm 0.32 \mathrm{~mm}$ (約 $100 \%$ ), $55^{\circ}$ で最小值 $4.17 \pm 0.45 \mathrm{~mm}$ （約 $83 \%$ ) となった. 運動距離の変化について, 顆頭中 央点は全運動軸点と比較して大きい. 矢状切歯路傾斜度 の約 $0^{\circ} \sim 20^{\circ}$ の範囲で両者は漸減し, 約 $20^{\circ} \sim 30^{\circ}$ の範 


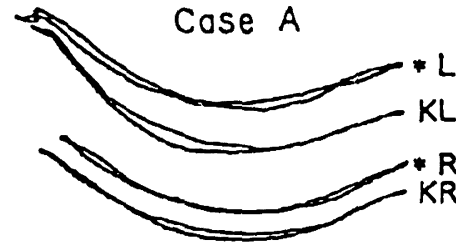

Case 8
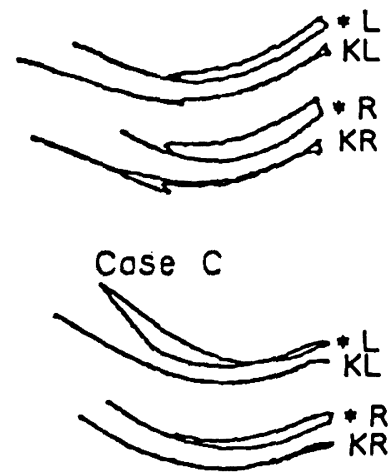

Cose D

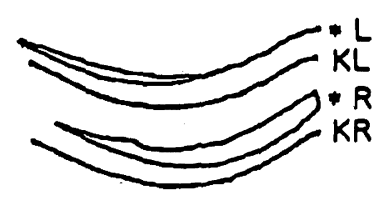

Cose $E$

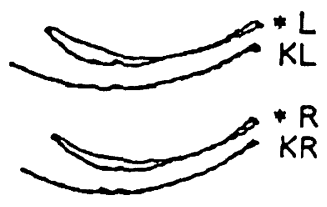

Cose $F$

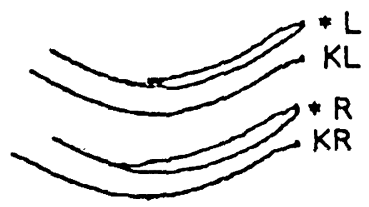

Cose G

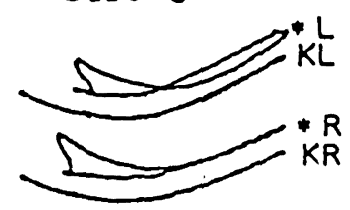

Case $H$

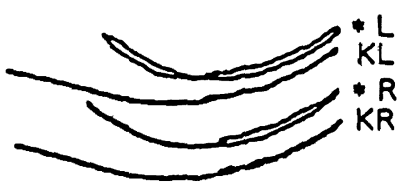

Case 1

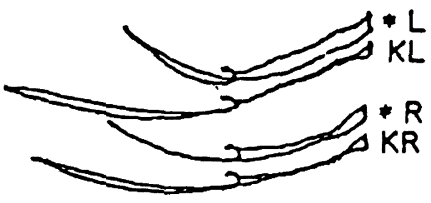

Case J

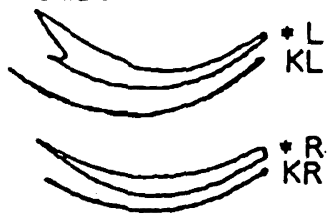

Case $K$

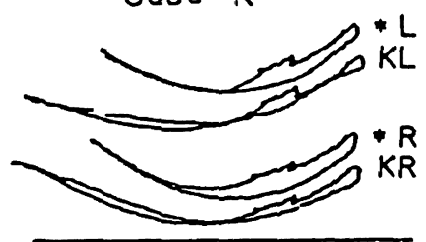

$\square 5 \mathrm{~mm}$

$K L$ : Kinematlc Axisis

Point ( Left)

$K R$ : Kinemotic Axisis

Point (Right)

* L : Central Point

of Condyle (L.)

-R : Central Point of Condyle (R.)

图 9 各被験者の矢状面限界運動時の顆頭運動路（顆頭中央点, 全運動軸点）

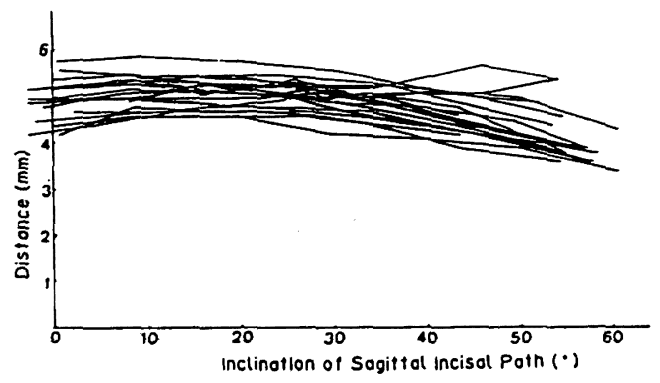

Condylor Path ( Distance): Central Point of Condyle

図 10 矢状切歯路傾斜度の変化が顆頭中央点の運動距離に 与える影響

囲で最も小さく，かつほとんど等しくなり，約 $30^{\circ}$ 以上 の範囲で増加した。

2) 矢状顆路傾斜度

切歯点で正中矢状方向への $5 \mathrm{~mm}$ の前方滑走運動で は，顆頭中央点および全運動軸点の描く軌跡は，多くの 被験者においてほぼ直線とみなすことができた.そこで,

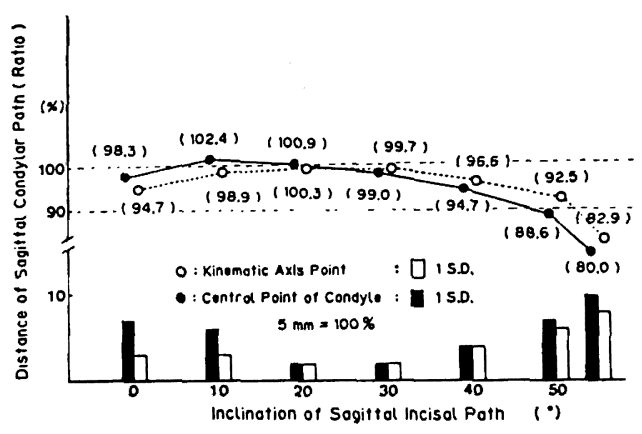

図 11 矢状切歯路傾斜度の変化が顆頭の運動距離に与 える影響（平均值と分散）

矢状顆路傾斜度は顆頭中央点および全運動軸点の軌跡に おいて, 出発点と切歯点で $5 \mathrm{~mm}$ 前方滑走した位置に対 応する点とを結ぶ直線が基準平面となす角度とした.

各被験者のデータは図 12-a，b に示した. 実線は顆頭 中央点 $(* \mathrm{~L}, * \mathrm{R})$ の軌跡のな寸矢状顆路傾斜度であり， 点線は，全運動軸点 $(\mathrm{KL}, \mathrm{KR})$ のなす矢状顆路傾斜度 
Case $A$

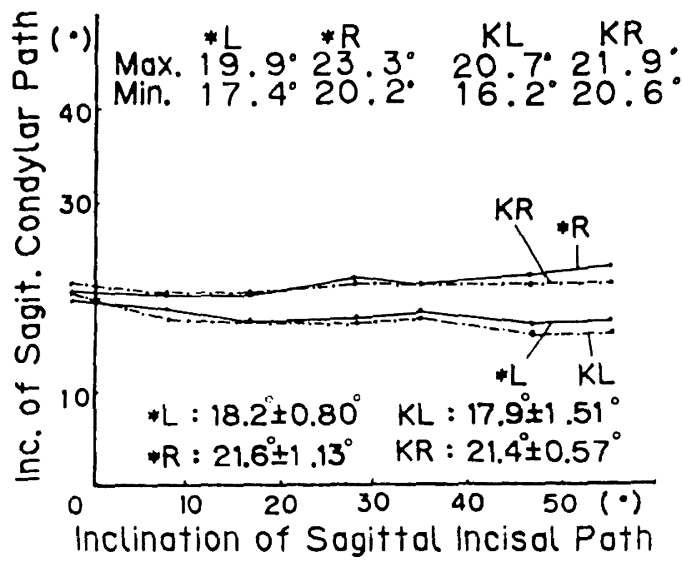

Case B

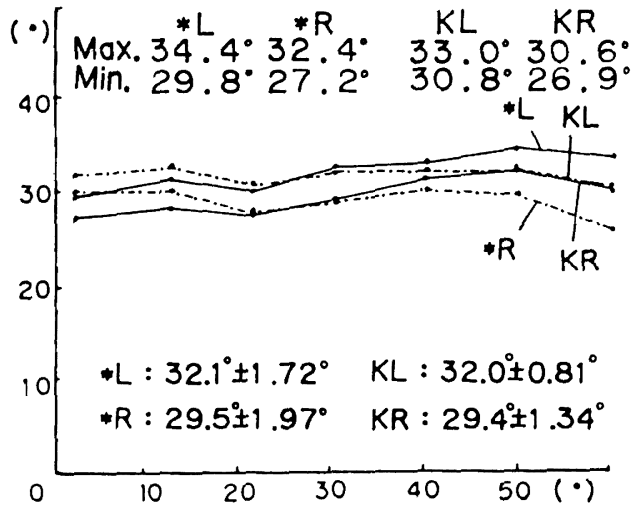

\section{Case C}

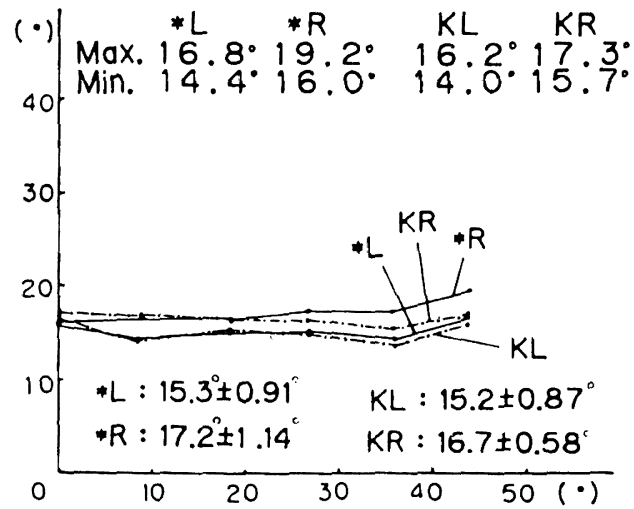

Case D

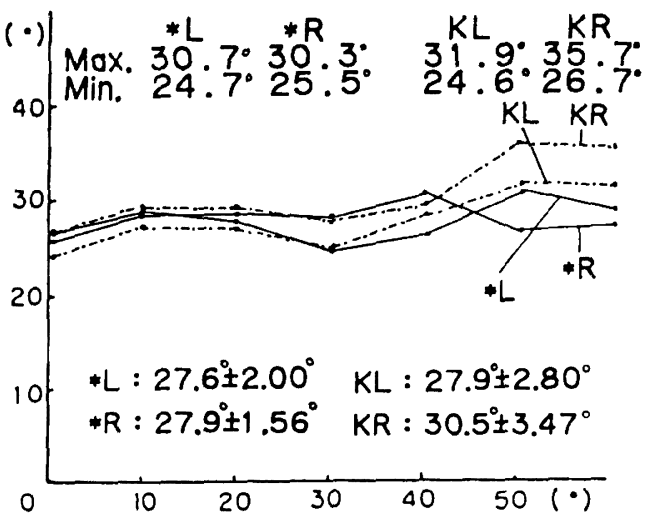

\section{Case $E$}

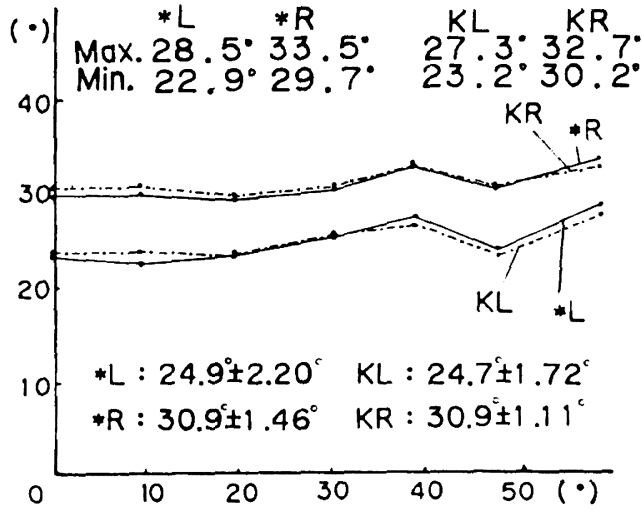

Case $F$

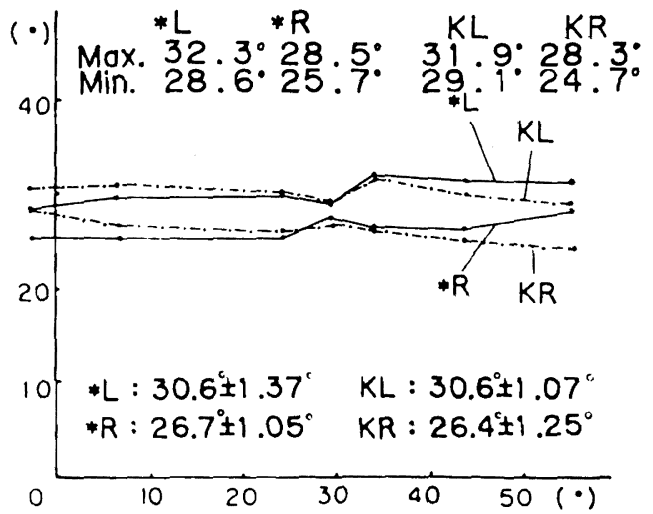

図 12-a 矢状切歯路傾斜度の変化が各被験者の矢状顆路傾斜度に与える影響（顆頭中央点, 全運動軸点） 
Case G

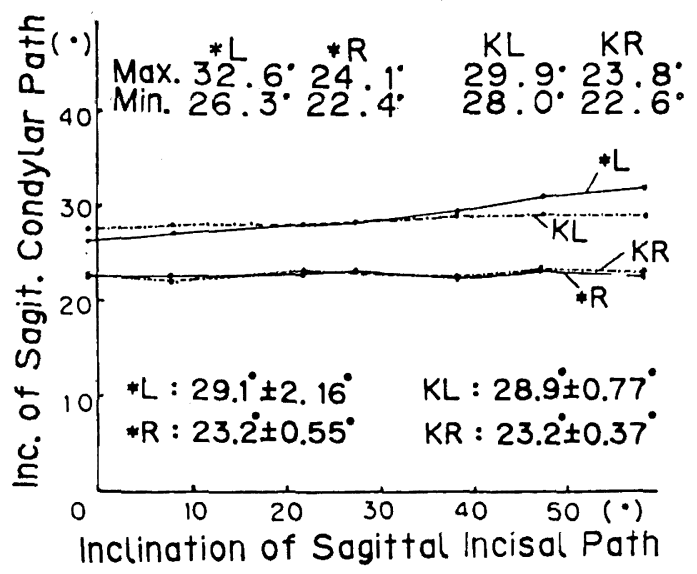

Case $H$

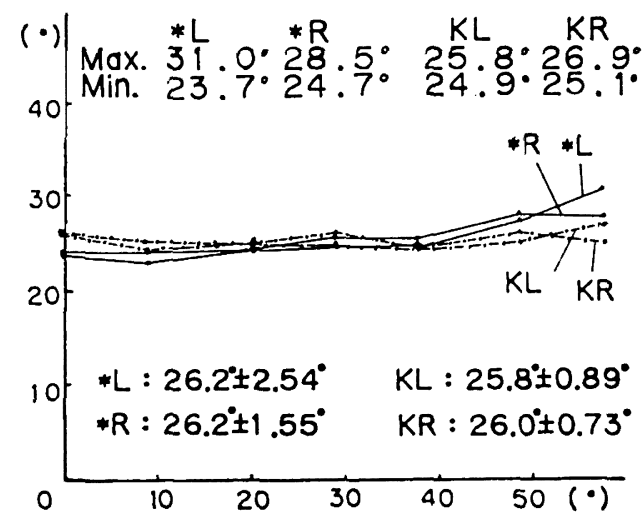

\section{Case 1}

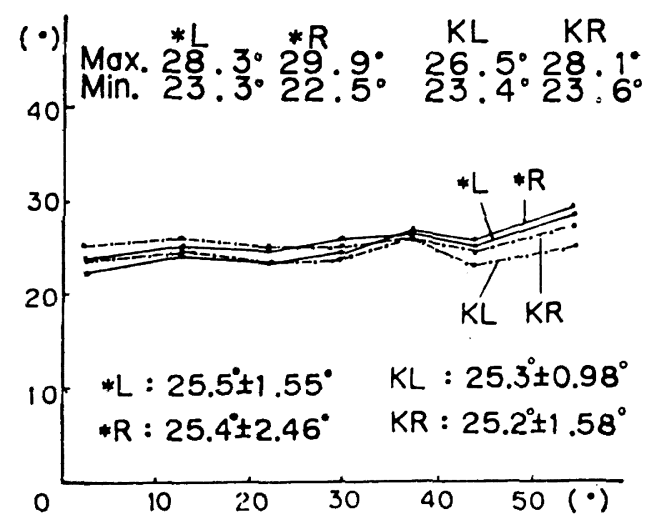

Case $J$

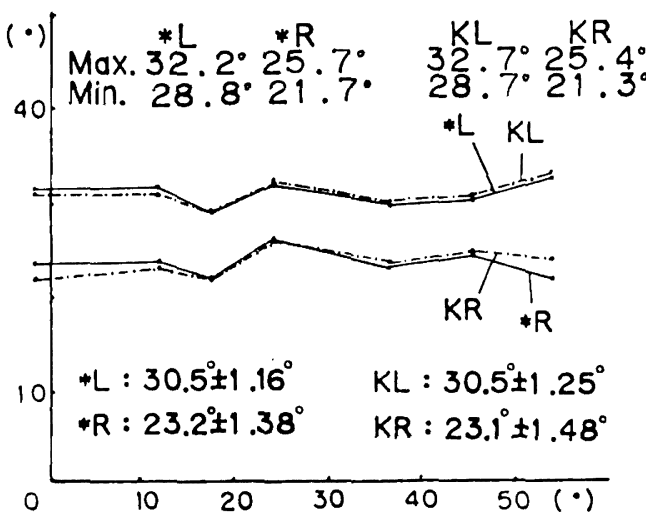

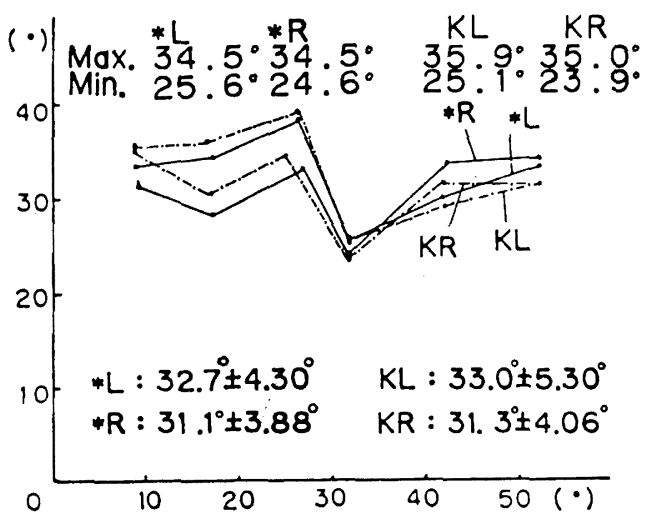

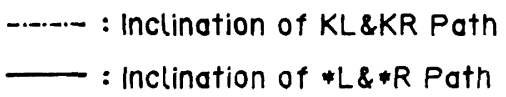

KL : Kinemotic Axisis Point ( Left) $K R$ : Kinematic Axisis Point (Right) *L : Central Point of Condyle (L.) *R : Central Point of Condyle ( R. )

图 12-b 矢状切歯路㑯斜度の変化が各被験者の矢状顆路傾斜度に与える影響（顆頭中央点, 全運動軸点） 


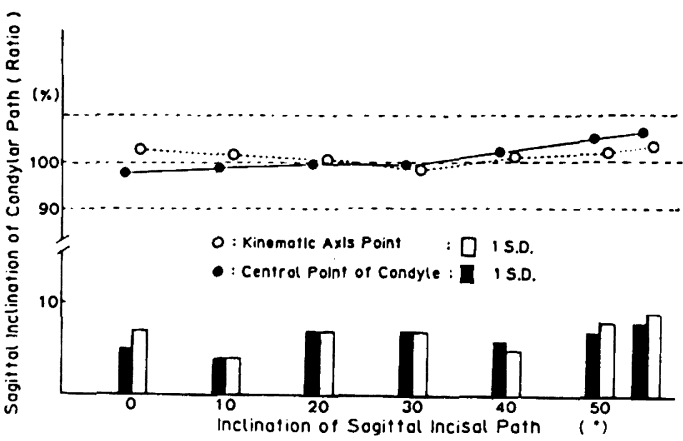

図 13 矢状切歯路傾斜度の変化が矢状顆路傾斜度に与える 影響 (平均値と分散)

である．両者の平均值および最大最小值は図 12-a， b の 各枠内に示した. 顆頭中央点のなす矢状顆路傾斜度の平 均値は $26.20^{\circ}$, 最小值は $14.40^{\circ}$, 最大值は $34.50^{\circ}$ で あった. 全運動軸点のなす矢状顆路傾斜度の平均値は $26.20^{\circ}$, 最小值は $14.00^{\circ}$, 最大値は $35.90^{\circ}$ であった.

左右の顆路傾斜度の差は, 顆頭中央点では $0.00^{\circ} \sim$ $7.30^{\circ}$ であり，全運動軸点では $0.10^{\circ} \sim 7.40^{\circ}$ であった。

図 13 亿矢状切歯路傾斜度を $30^{\circ}$ としたときの矢状顆 路傾斜度を基準とし，各矢状切歯路傾斜度に対する各矢 状顆路傾斜度の変化を百分率で示した．黒丸は顆頭中央 点, 白丸は全運動軸点である. 下の棒グラフはそれぞれ の分散を示している. 約 $0^{\circ} \sim 60^{\circ}$ までの矢状切歯路傾斜 度の変化に対する顆頭中央点のなす矢状顆路傾斜度の平 均值は, 矢状切歯路傾斜度の増加に伴い漸增した. 全運 動軸点のなす矢状顆路傾斜度の平均值は, ほとんど変化 しなかった. 矢状顆路傾斜度の分散は一定した傾向はみ られなかったが，約 $20^{\circ} \sim 30^{\circ}$ の範囲では，顆頭中央点 と全運動軸点とは, ほぼ等しかった.

\section{IV. 考察}

\section{1. 全運動軸点について}

影関節における顆頭の運動軌跡の特徵は, 顆頭の形態 的特徵に関倸していると考えられるので, 全運動軸点は 顆頭内に存在するか, あるいは顆頭と解剖学的に一定の 位置関係とならなければならないと考えられる。

従来の報告1 3, 12 16) では，全運動軸点はほとんどが平 均的顆頭点の近くに位置していたが，本研究の被験者で は, 図 8-a, b に示したように, 全運動軸点の存在位置 が顆頭外に大きく外れる例や (Case B, I, K の 3 名 6 顆頭)また，前者ほどではないが Case C, E, F, G, H の 5 名 8 顆頭のように顆頭外に外れる傾向のある例がみら
30 巻 1 号 (1986)

れた. 全運動軸点, 平均的顆頭点間の距離の平均值で比 較すると，従来の報告の約 2.7 倍となり，全運動軸点の 位置が，特に前上方に位置する例が多くみられた。

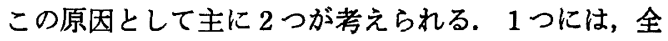
運動軸点は運動形態から決定される顆頭点 ${ }^{17 ~ 24) て ゙ あ る ~}$ ためと考えられる. 全運動軸点は下顎の矢状面内運動に おいて，運動軌跡の矢状面投影図での上下幅が最小とな る下䇗上の点として定義されている. しかし，上下幅が 完全に一致することは生体においては難しいい.

もう1つは，被験者の条件が関係しているためと考え られる. 本研究の被験者では, 従来の報告のように年齢 の若い正常有歯顎者とは，異なり，年齢が高く（平均約 59 歳), 歯牙の欠損のために咬合関倸が定まらない不良 な咬合関倸の既往があった，このような被験者群では， 䫟関節において顆頭と関節円板や勒帯などの顆頭の周囲 の組織との関係が変化したために, 顆頭の運動軌跡も影 響を受け, 全運運軸点の位置が, 顆頭内の狭い領域には 存在しにくくなっていると考えられた ${ }^{25)}$.

さて, 前者では, 顆頭の運動軌跡のどの部分に重点を おいて上下幅を最小とするかの決定基準1 3,12 16) の違い によっても全運動軸点の位置は異なるが，本研究の被験 者ほど大きく変位する例は，みられなかった，また，本 研究の決定基準 ${ }^{11}$ も従来のものとほとんど異ならないこ とから (付録 1), 全運動軌軸点の位置変化は後者の理由 によることが大きいと考えられた。

また，文頭で述べたように，全運動軸点の位置が顆頭 外に不規則に外れ，顆頭の運動形態との一定した関倸が 見出されないときには，全運動軸点も運動論的に求まる 単なる特殊点にすぎないが，本研究の多くの被験者の全 運動軸点が前上方に変位していたことから，全く不規則 に変位しているわけではなく，顎関節に構造的な変化が あるときに，全運動軸点の変位し易い方向があると考え られた。

2. 矢状切歯路傾斜度の変化が矢状顆路に与える影響 矢状切歯路傾斜度の影響を, 顆頭の運動距離と運動方 向（矢状顆路傾斜度）について検討する.

1）運動距離に与える影響

全運動軸点のなす矢状顆路傾斜度は, 矢状切歯路傾斜 度の変化の影響を受けにくいので顆頭点として幾何学的 に検討し易い基準点である.

全運動軸点の運動距離 d を決定するパラメータは切歯 点の運動距離 $\mathrm{a}$, 矢状面に投影した切歯点・全運動軸点 間距離 $\mathrm{L}$, 矢状切歯路傾斜度 $\phi$, 切歯点と全運動軸点と 

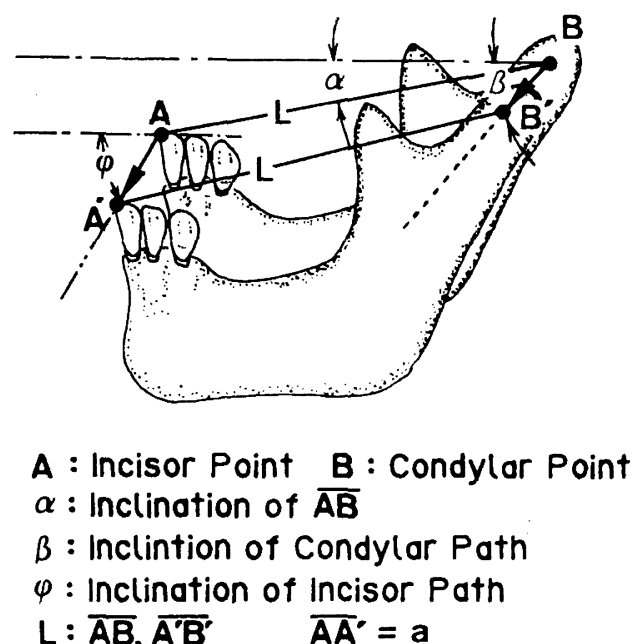

$L: \overline{A B}, \overline{A^{\prime} B^{\prime}} \quad \overline{A A^{\prime}}=a$

$\mathbf{d}: \overline{\mathrm{BB}}^{\cdot}=\mathbf{F}(\alpha, B, \varphi, \mathrm{L}, \mathbf{a})$

図 14 全運動軸点の運動距離 (d)

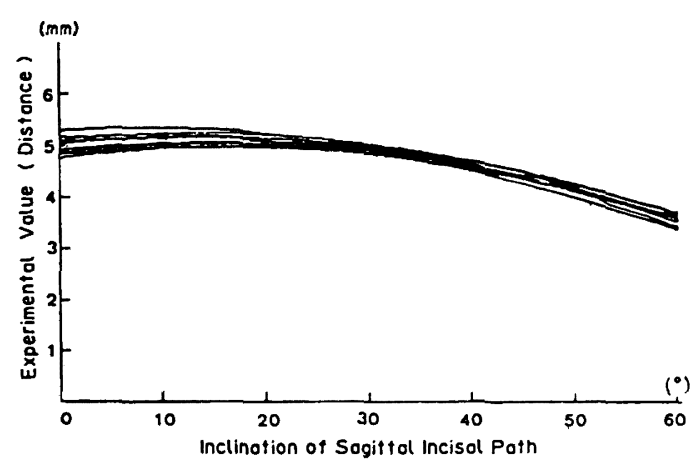

图 15 全運動軸点の運動距離の計算値

を含む平面が基準平面となす角度 $\alpha$, 矢状顆路傾斜度 $\beta$ である.

すなわち，全運動軸点の運動距離 $\mathrm{d}$ は $\mathrm{a}, \mathrm{L}, \phi, \alpha, \beta$ の関数として,

$$
\begin{aligned}
\mathrm{d}=\mathrm{F} & \mathrm{F}, \mathrm{L}, \phi, \alpha, \beta) \\
= & \mathrm{a} \cos (\phi-\beta)+\mathrm{L} \cos (\beta-\alpha) \\
& -\left[\{\mathrm{a} \cos (\phi-\beta)+\mathrm{L} \cos (\beta-\alpha)\}^{2}\right. \\
& \left.-\left\{\mathrm{a}^{2}+2 \mathrm{a} L \cos (\phi-\alpha)\right\}\right]^{1 / 2}
\end{aligned}
$$

と表される (図 14). 本研究では切歯点の運動距離を 5 $\mathrm{mm}$ としたので $\mathrm{a}=5$ とした.

式 (1) は実際のデータにその傾向は良くあてはまった (図 10,15).

さて，ここで式 (1) の性質について詳しく検討する.

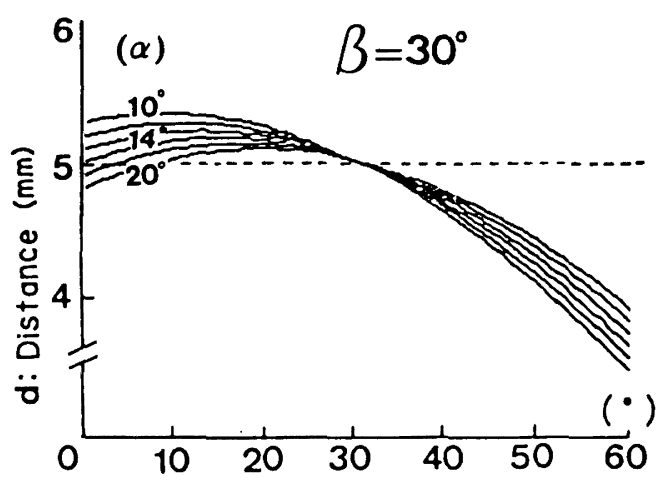

$\varphi$ : Inclination of Sagittal Incisal Path

図 $16 \alpha$ (切歯点と顆頭点を含む平面が基淮平面とな 寸角度) の影響

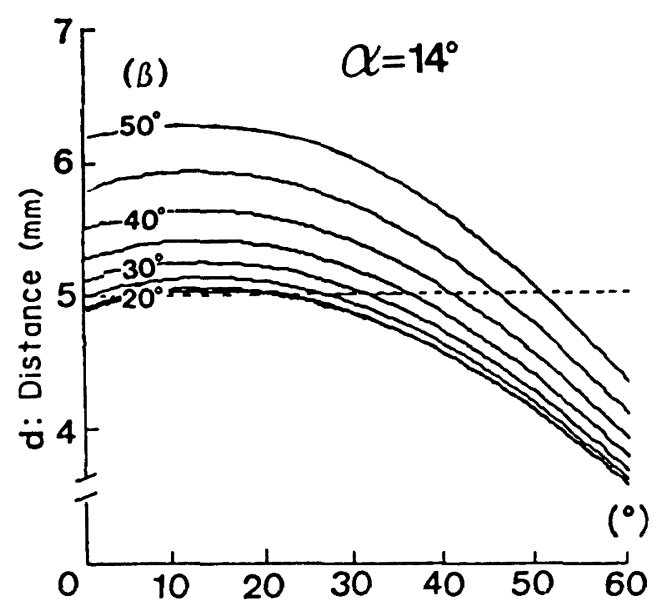

$\varphi$ : Inclination of Sagittal Incisal Path

図 $17 \beta$ (矢状顆路傾斜度) の影響

i）切歯点と全運動軸点とを結ぶ線分が基準平面とな す角度 $\alpha$ の影響

$\alpha$ の影響を調べるために， $\alpha$ をパラメータとし， $\phi$ d との関係を図 16 に示した.

本研究の被験者は, $\alpha$ が $10.0^{\circ} \sim 17.5^{\circ}$ (平均 $14.2^{\circ} \pm$ $\left.2.1^{\circ}\right)$ の範囲の值であったので $\alpha$ を $10^{\circ}$ から $2^{\circ}$ おきに $20^{\circ}$ まで変化させた. 他のパラメータ $\beta, \mathrm{L}$ は平均值に 近い值の $30^{\circ}, 100 \mathrm{~mm}$ とした.

この場合 $\alpha=\phi$ のときに $\mathrm{d}$ は最大值 $\mathrm{d}_{\max }$ をとり, $\alpha$ が減少すると $\mathrm{d}_{\max }$ は増大した.

ii）矢状顆路傾斜度 $\beta$ の影響

$\beta$ の影響を調べるために, $\beta$ をパラメータとし， $\phi$ と $d$ の関係を図 17 に示した.

本研究の被験者は, $\beta$ が $15.3^{\circ} \sim 32.7^{\circ}$ (平均 $26.2^{\circ} \pm$ 

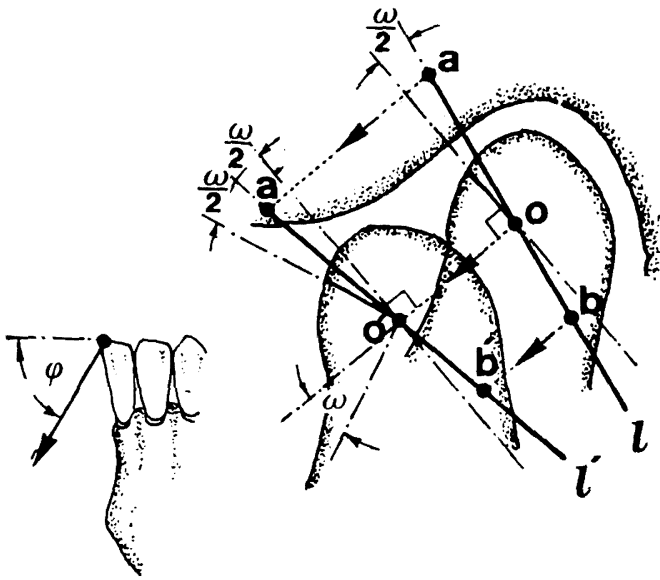

図 18 全荤動軸点の運動方向 $\left.4.8^{\circ}\right)$ の範井の值であったので $\beta$ を $15^{\circ}$ から $5^{\circ}$ おきに $50^{\circ}$ まで変化させた，他のパラメータの $\alpha, \mathrm{L}$ 位平均值 の $14^{\circ}, 100 \mathrm{~mm}$ とした.

この場合， $\beta=\phi$ のときに $\mathrm{d}=5 \mathrm{~mm}$ となり, また $\phi>\beta$ のときに $\mathrm{d}<5 \mathrm{~mm}$ となった.

iii）矢状面に投影した切歯点 · 顆頭点閒距離 L の影 䡒

本研究の被験者は, L が 88.0 105.0 mm (平均 97.4 $\pm 4.5 \mathrm{~mm}$ ) の範囲の值であったが, この程度の範囲の $\mathrm{L}$ の変化では，dの值に影響はなかった。

以上をまとめると,つぎのようになる。

1. 矢状切歯路傾斜度 $\phi$ が矢状顆路傾斜度 $\beta$ よりも 大きいときは, 全運動軸点の運動距離 $\mathrm{d}$ は常に切歯点の 運動距離 $\mathrm{a}$ よりも小さく, $\mathrm{d}$ の減少率は切歯点と全運動 軸点とを含む平面がカンペル平面となす角度 $\alpha$ が小さ いほど大きい。

2. $\phi$ が $\beta$ よりも小さいときは, $\mathrm{d}$ は $\mathrm{a}$ よりも大きく なることがある. $\alpha$ が，より小さいほどdはより大きく なる，矢状顆路傾斜度 $\beta$ が $20^{\circ}$ 以下では全運動軸点の 運動距離 $\mathrm{d}$ が切歯点の運動距離 $\mathrm{a}$ より大きくなることは ほとんどない。

3. 切歯点 - 全運動軸点間の距離 $\mathrm{L} の$ 変化は, 全運動 軸点の運動距離 $\mathrm{d}$ にほとんど影響を与えない.

さて図11において顆頭中央点と全運動軸点の運動距離 に対する矢状切歯路傾斜度の影響の違いは（全運動軸点 の運動距離に最大值を与える矢状切歯路傾斜度の值が, 顆頭中央点の運動距離に最大値を与える矢状切歯路傾斜 度の值と比較して大きく，その時の全運動軸点の運動距 離は顆頭中央点の運動距離と比較して小さい), 多くの
30 巻 1 号 (1986)

被験者で全運動軸点の位置が顆頭中央点より上方に位置 することによって $\alpha$ が大きくなるためである（図 8-a， b, 16）と考えられる. また，運動距離の分散が大きくな る理由は, 顆頭中央点では, 矢状顆路傾斜度が矢状切歯 路傾斜度の関数となって，変化するためと考えられる.

なお, 矢状切歯路傾斜度の変化に対する顆頭の運動距 離に着目すると，咬合を再構成するときに，顆頭の運動 距離が過大にならないように配慮する必要があることが ある. たとえば，矢状切歯路傾斜度が矢状顆路傾斜度よ り小さいときに，顎機能に異常がおきる危険性があると されている27,28)が, この原因は顆頭の逆回転運動に加え て, 顆頭の運動距離が過大に大きくなることによって, その間に何らかの障害を受け易くなるといら可能性が高 くなることも考えられる.

\section{2）矢状顆路傾斜度に与える影響}

全運動軸点以外の任意の顆頭点の運動軌跡は, 下顎の 回転運動の影響を受けてそれぞれ異なる、ここでは，全 運動軸点を基準として，任意の顆頭点のなす矢状顆路傾 斜度の変化について検討し, 任意の顆頭点, 特に顆頭中 央点のなす矢状顆路傾斜度の変化を全運動軸点との位置 関係によって幾何学的に考察した.

(1) 矢状顆路傾斜度の変化 ${ }^{26)}$

本研究では, 顆頭の運動軌跡を, 中心位と切歯点で 5 $\mathrm{mm}$ の前方位に対応する顎位との 2 颚位間のデータで近 似している.

このとき，運動軌跡は異なるが，全運動軸点以外の任 意の顆頭点のうちで，下顎の回転運動の影響を受けない 点の存在することがわかった. 図 18 は切歯点で矢状切 歯路傾斜度 $\phi$ を与えて, 前方滑走運動をさせたときの下 䕱の回転運動について示している. 図中の。は全運動軸 点である. 直線 $l$ は全運動軸点 0 を通り, 全運動軸点の 移動方向に対して $\pi / 2+\omega / 2$ 逆回転した角度をもつ線分 である. 直線 $l$ 上の点 $\mathrm{a}, \mathrm{b}, \mathrm{o}$ 汇顆頭の回転と移動とに よって直線 $l^{\prime}$ 上の点 $\mathrm{a}^{\prime}, \mathrm{b}^{\prime}, \mathrm{o}^{\prime}$ に位置を変化させるが, $\omega$ 回転しているので, $\mathrm{aa}^{\prime}, \mathrm{bb}^{\prime}, \mathrm{oo}^{\prime}$ は，運動軌跡は異な るが，運動方向は同じになる.このようにして，值線 $l^{\prime}$ 上の点列は, すべて $00^{\prime}$ (全運動軸点のなす矢状顆路傾 斜度）と同じ運動方向となる。

矢状切歯路傾斜度の変化に対する任意の顆頭点の矢状 顆路傾斜度の変化は, この直線 $l$ との位置関係によって 説明される. 全運動軸点を通り $\pi / 2+\omega / 2$ 逆回転した角 度をもつ直線より前方にある任意点では，回転運動の影 響を受け矢状顆路傾斜度を増し，後方に存在する点では 矢状顆路傾斜度を減ずる. この直線 $l$ 上の点では回転運 
動の影響を受けない.

そこで図 8-a, b に示した各被験者の顆頭中央点と全 運動軸点との位置関係を調べた、その結果, 顆頭中央点 の位咱が全運動軸点を通り矢状顆路と直交する直線 $l$ よ り前方に位置するものが最も多く，この直線上に位置す るものは 4 名 4 顆頭 (Case C の左, E の右, G の右, J の 左側) であり, 後方に位置するものは, Case J の右側顆 頭のみであった.

さらに, 各被験者の顆頭中央点の矢状顆路傾斜度の変 化 (図 12-a, b) をみると, 顆頭中央点が直線 $l$ 前方に 位置するとき (Case A の左右, B の左右, C の右, $\mathrm{E}$ の 左, $\mathrm{F}$ の左右, $\mathrm{G}$ の左, $\mathrm{H}$ の左右, I の左右側顆頭) は, 矢状切画路傾斜度の増加に伴い, 全運動軸点のなす矢状 顆路傾斜度と比較して顆頭中央点のなす矢状顆路傾斜度 は増加した. 直線 $l$ 上にあるとき(Case C の左, $\mathrm{E} の$ 右, $\mathrm{G}$ の右, J の左側顆頭) は全運動軸点と顆頭中央 点とがなす矢状顆路傾斜度は同じであった. 值線 $l$ の後 方に位置するとき (Case J の右側のみ) は全運動軸点と 比較して顆頭中央点とがなす矢状顆路傾斜度 は減少し た.

これらより, 矢状切歯路傾斜度の変化が顆頭の運動方 向 (矢状顆路傾斜度) に与える影響について説明できた. また, 全運動軸点と位置が一致していなくても, 矢状顆 路傾斜度が，全運動軸点と同じになる顆頭点の存在する 理由が説明された. なお, Case D, K では顆路が非常に 不安定で, 矢状切歯路傾斜度の影響を大きく受けたので, 以上のような結果は必ずしもあてはまらなかった。

図 13 において, 顆頭中央点のなす矢状顆路傾斜 度 が 始めは平均値より小さく, 矢状切歯路傾斜度の增加に伴 って漸増するのは, 顆頭中央点の位置が前述した直線 $l$ より前方に位置する被験者が多いためである.すなわち, 始めは矢状切歯路傾斜度より矢状顆路傾斜度が大きいた

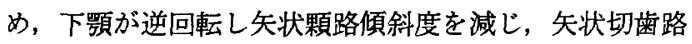
傾斜度が増加するにしたがって, 下顎が正回転して矢状 顆路傾斜度を増すためである (付録 2 参照). また, 矢状 切歯路傾斜度が約 $20^{\circ} \sim 30^{\circ}$ の範囲では顆頭中央点と全 運動軸点とのなす矢状顆路傾斜度がほぼ等しいのは, 下 顎が回転運動を伴わないことにより，どの顆頭点もほと んど同じ方向に運動するためであると考えられる.

(2) 矢状顆路傾斜度の再現性

a. 前方滑走運動時の矢状顆路傾斜度の再現性 ${ }^{26)}$

ここでは, 矢状顆路傾斜度の再現性を検討するために, 任意の顆頭点における矢状切歯路傾斜度の変化に対する 最大の顆路傾斜度と最小の顆路傾斜度との差 $\theta$ を考え

\section{$\theta$ : The Difference between Maximum \& Minimum Inclination of the Condylar Path}
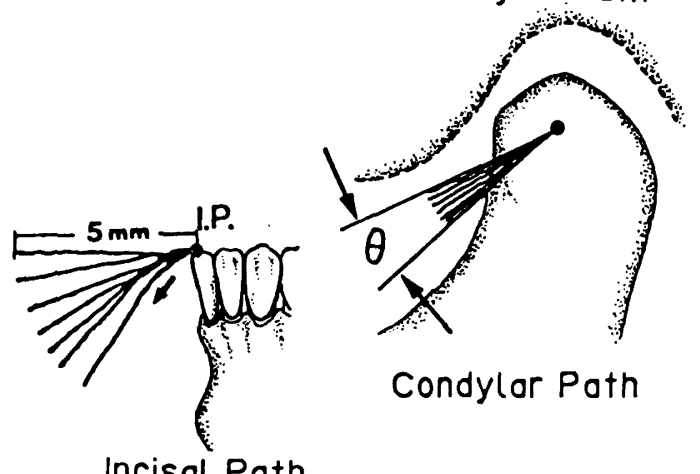

Condylar Poth

Incisal Poth

図 19 顆路傾斜度差 $\theta$

て, 任意の顆頭点での $\theta$ の最小值 $\theta_{\min }$ を矢状顆路傾斜 度の再現性と考えた（図 19）.

また，任意の顆頭点において， $\theta$ が等しくなる点列を 結び，等顆路傾斜度差線とし，図 20-a, b に示した. 実 線が等顆路傾斜度差線であり， $1^{\circ}$ 間隔で表示した. 白丸 は全運動軸点である. 斜線で示す領域は, $\theta_{\min }$ が含まれ る領域である.

等顆路傾斜度差線は, 前傾していてほぼ直線状をなし， その傾きは平均で約 $63.6^{\circ} \pm 5.1^{\circ}\left(57.5^{\circ} \sim 75.5^{\circ}\right)$ であ った．各被験者の等顆路傾斜度差線は，ほぼ矢状顆路と 直交した.

$\theta_{\min }$ を囲む領域は顆頭部を通るか, あるいは顆頭に近 接して帯状となった. 全運動軸モデルが完全であり, 測 定誤差もなければ, 矢状顆路傾斜度の再現性の良い点は， 各矢状切歯路傾斜度に対する等顆路傾斜度差線の交点, すなわち全運動軸点として求まるはずである.しかし， 下顎の回転角 $\omega$ の值が非常に小さく (付録 2 参照), 任 意の顆頭点の顆路傾斜度差 $\theta$ の変化も等顆路傾斜度差線 に沿った方向ではきわめて小さい（付録 3 参照）ことに 加え, 生体のデータであることや実験誤差のために, 点 ではなく等顆路傾斜度差線の团む帯状の領域となり, 全 運動軸点の軌跡に直交すると考えられる.

さて, 本研究の被験者では, $\theta_{\min }$ の值は 11 名 22 顆頭 では, $0.7^{\circ} \sim 10.5^{\circ}$ となり，個人差が大きく認められた. 全運動軸点であっても矢状顆路傾斜度の再現性が悪い例 （図 12-a, 12-b の Case D, K) もみられた.

しかし, 問題となるのは, 全運動軸点で $\theta_{\mathrm{min}}$ の值が 


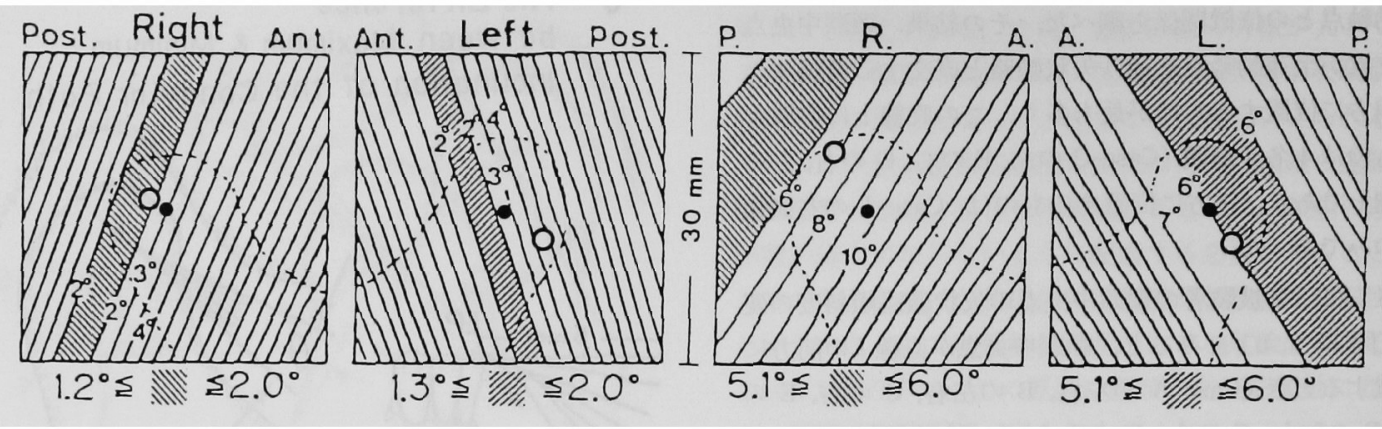

Case B

Case $E$
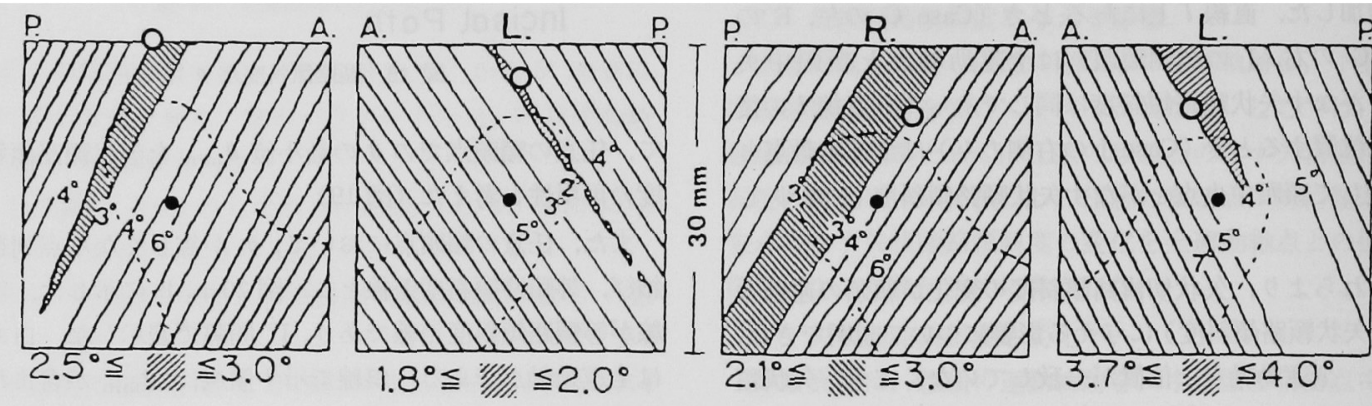

Case $C$

\section{Case $F$}

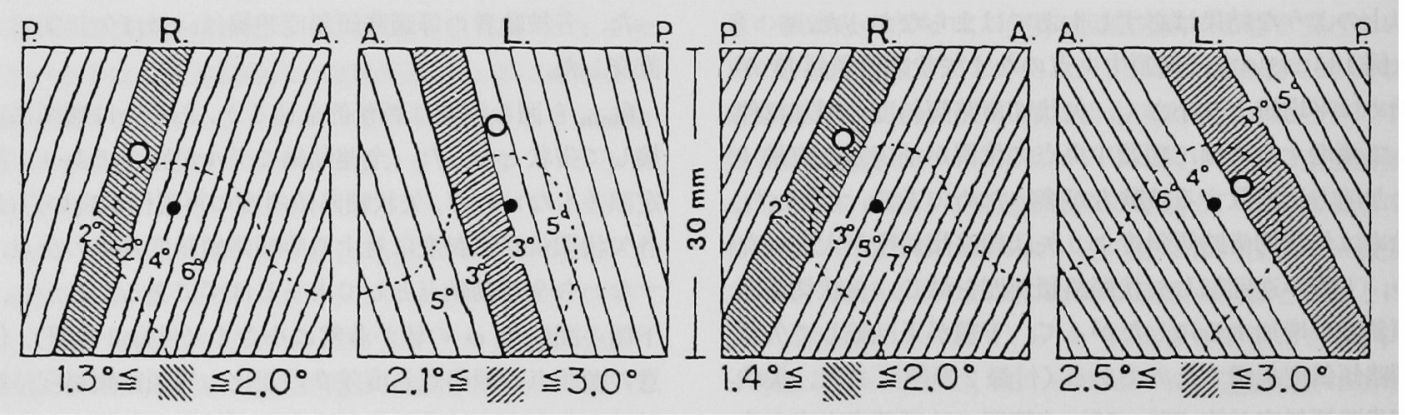

図 20-a 全運動軸点の位置と等顆路傾斜度差線の分布

$2^{\circ} \sim 3^{\circ}$ と再現性が良いのにもかかわらず，顆頭中央点で 約 $5^{\circ}$ 以上となり, 再現性の悪い 5 名 6 顆頭の例 (Case B, G, H の左側顆頭, Case B, F, I の右側顆頭) である. これらの被験者では，解剖学的顆頭点で顆路傾斜度の測 定をすれば，矢状切歯路傾斜度の影響を受けるので，大 きな誤差を生じることになる.

\section{b. 臨床との関連}

本研究では, 全運動軸点は 9 名 13 顆頭が $\theta_{\min }$ の領域 に存在し, 他の被験者の顆頭でも $\theta_{\mathrm{min}}+1^{\circ}$ 以内の領域 に存在した．臨床で, 顆路の再現性が必要とされる場合, 全運動軸点を求めることが望ましいと考えられる.

下顎が回転量の異なる運動を行ったとき, 顆路傾斜度 の差 $\theta$ が最小の顆頭点, すなわち矢状切歯路傾斜度の影 
Case G

Case J
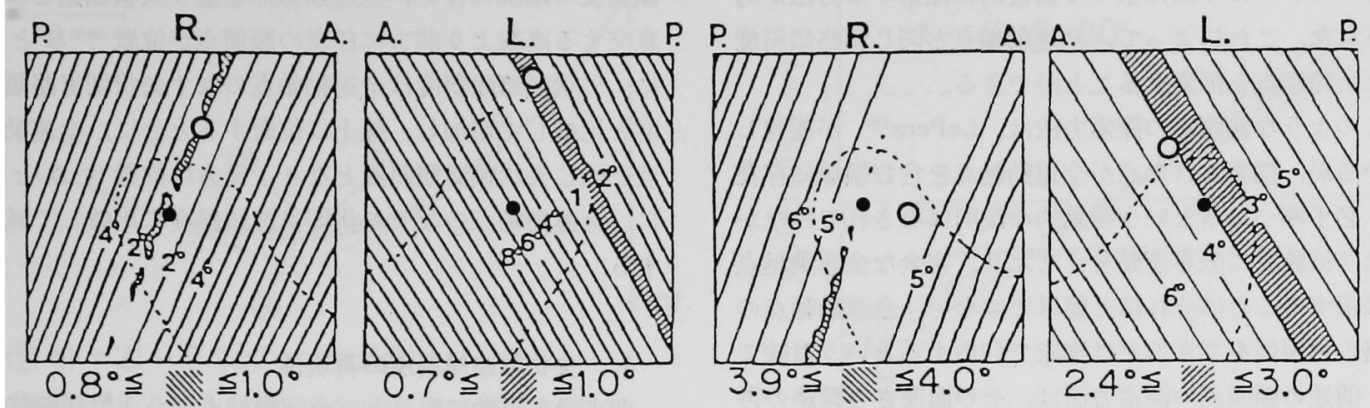

Case $\mathrm{H}$

Case $K$
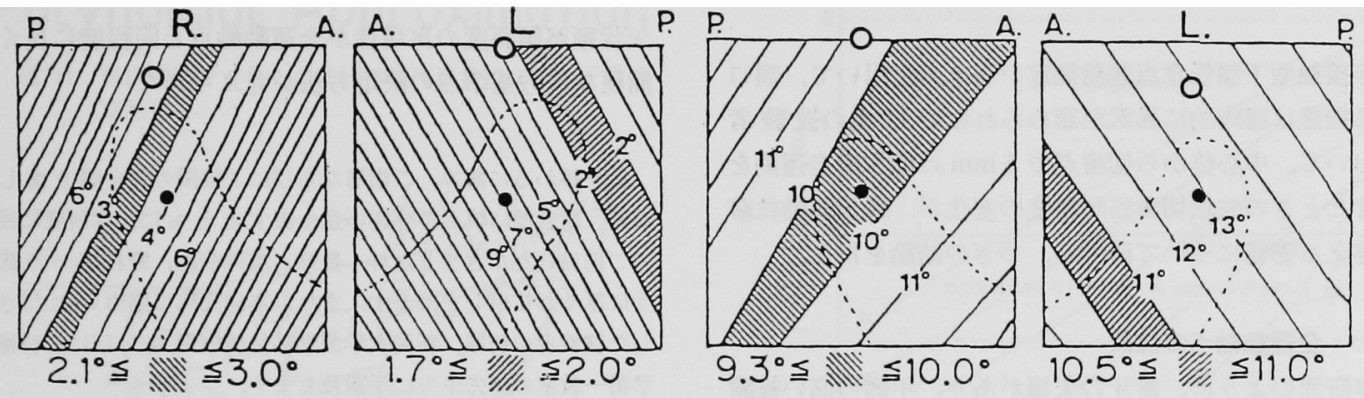

\section{Case 1}
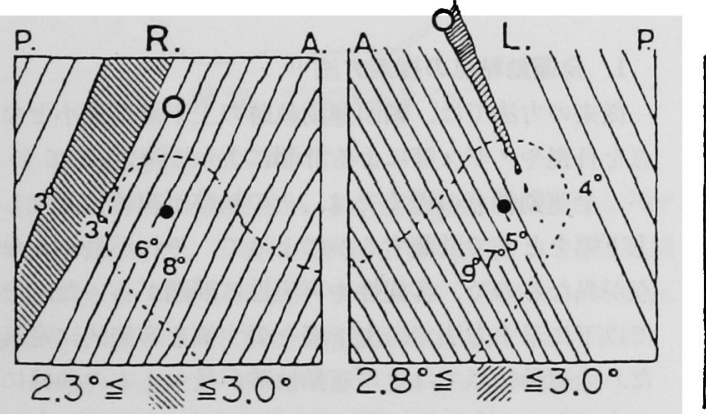

W/: Small $\theta$ oreo

$\theta$ : The Difterence between Moximum \& Minimum

Inclination of the Condylor Path

0 : Kinemotic Axis Point

- : Centrol Point of Condyle

図 20-b 全運動軸点の位置と等顆路傾斜度差線の分布

響を最も受けない顆頭点についてつぎのことがわかって いた.

1. 矢状切歯路傾斜度の変化に対して, 矢状顆路傾斜 度，および切歯点と全運動軸点とを含む平面がカンペル 平面とでなす角度の 3 者の影響を主に受ける. 矢状切歯 路傾斜度が矢状顆路傾斜度より小さいときには, 全運動 軸点の運動距離は切歯点よりも大きくなる. また, 切歯 点と顆頭点とを含む平面とカンペル平面とでなす角度が
小さいときには, 全運動軸点の運動距離はさらにその差 が最も小さくなる顆頭点は必ず存在し, その存在する領 域は上下方向に長く, 前傾し, 帯状となった。

2. 帯状の領域は, 全運動軸点をほとんど確実に含ん た.

以上から下䫟に異なる回転量を与える 2 つの運動（下 䫟の回転量の最も小さな前方滑走運動と回転角の比較的 大きな開閉口運動）をさせたときに生じる矢状顆路傾斜 
$124-124$

度差が最も小さくなる顆頭点の領域を, 平均的顆頭点を 中心にカンペル平面に沿って前後的に探索する方法が考 えられた.これによって, 全運動軸点と同じ顆路傾斜度 をなす顆頭点を探索することができる.

このような顆頭点の探索方法は, LePera ${ }^{29)}$ が報告し ているが，探索された点が全運動軸点を含む領域に存在 し，必ずみつかるという理論的な説明はなされていなか った. 被験者に限界運動をさせたり，完全な全運動軸点 を探索することはそれほど简単ではない，全運動軸点の 顆路の再現性をできるだけ臨床で利用するという意味で は，前述の顆頭点の探索方法は，その簡便さと顆路の再 現性とを考えると有効と考えられる.

\section{V. 結 論}

非接触型下滪任意点運動測定システムを用いて，頻口 腔系機能は臨床的に異常が認められない11名の被験 者 において, 中心位から切歯点で $5 \mathrm{~mm}$ の前方滑走運動を させたときの矢状切歯路傾斜度の変化が, 顆頭運動軌跡 に与える影響について研究し,つぎの結論を得た.

\section{1. 全運動軸点の位置}

本研究のように，歯牙の欠損があり，年齢の高い被験 者では, 従来の報告と比較して全運動軸点の位置が正常 有歯䪶者と異なり, 前上方へ変化する例が多かった。 ま た，全運動軸点自体の顆路の再現性が悪い例もみられた. これによって，不良な咬合関倸の既往や年齢のために， 頢関節の運動形態に変化が起きる可能性が示唆された.

\section{2. 矢状切歯路傾斜度の変化が顆頭の運動距離に与え る影響}

全運動軸点の運動距離は, 切歯点の運動距離を一定と したときに, 矢状切歯路傾斜度, 全運動軸点のなす矢状 顆路傾斜度，および切歯点と全運動軸点とを含む平面が カンペル平面とでなす角度の 3 者の影響を主に受ける. 矢状切歯路傾斜度が矢状顆路傾斜度より小さいときに は, 全運動軸点の運動距離は切歯点よりも大きくなる. また, 切歯点と顆頭点とを含む平面とカンペル平面とで なす角度が小さいときには, 全運動軸点の運動距離はさ らに大きくなる.

\section{3. 矢状切站路傾斜度の変化が矢状顆路傾斜度に与元 る影響}

前方滑走運動時に，任意の顆頭点の矢状顆路傾斜度は
30 巻 1 号 (1986)

矢状切歯路傾斜度の影響を受けて変化する. 矢状切歯路 傾斜度の増加に伴い, 全運動軸点を通り矢状顆路とほほ 直交する直線より前方に任意の顆頭点が位置するとき に, 矢状顆路傾斜度は全運動軸点のなす矢状切歯路傾斜 度と比較して増加し，線上に位置するときに, 全運動軸 点と同じ矢状顆路傾斜度となり，後方に位置するとき に, 全運動軸点のなす矢状切歯路傾斜度に比較して減少 する.

\section{4. 矢状顆路傾斜度の再現性}

前方滑走運動に限ると，全運動軸点のなす矢状顆路傾 斜度と同程度に, 矢状顆路傾斜度の再現性の良い任意の 顆頭点の存在する帯状の領域が顆頭部を通り, 全運動軸 点はその中に含まれることがわかった.これを利用して， 矢状顆路傾斜度の再現性が全運動軸点と同程度に良く， 簡便な後方基準点の決定方法が考えられた.

稿を終わるに臨み,ご指導ならびにご校閱の労を賜りました 石岡 靖教授に慎んで感謝の意を表すとともに, 本研究に種々 のご助言いただきました林 豊彦, 塩澤恭郎, 野村修一の諸先 生に厚くお礼申し上げます。 また，本研究にご協力いただきま した被験者の皆様, 新潟大学歯学部付属病院ならびに歯科補緅 学第一教室の諸先生方に深謝致します.

\section{VI. 付 録}

\section{1. 全運動軸点の探索方法 ${ }^{11}$}

従来の方法では, 顆頭運動軌跡の上下幅が最小となる 点を目視やノギス等による計測によって決定していた が, 全運動軸点の近くでは, その軌跡が複雑に変化し, 上下幅をどこで計測するかによって，それが最小となる 点が異なるので, 客観性や再現性に問題があった. そこ で以下に示す方法で, 上下幅を表す值を客観的に定義し た. 全運動軸点ではその運動軌跡が最も1本の曲線に近 い点であることから，図21 に示すように運動データ $\left(X_{i}, Z_{i}\right)$ に, 近似曲線 $Z=F(X)$ をあてはめ, その曲 線とデータとの上下方向の距離 $\mathrm{e}_{\mathrm{i}}=Z_{\mathrm{i}}-\mathrm{F}\left(\mathrm{X}_{\mathrm{i}}\right)$ を上下 方向の厚みとみなした，そして，この $\mathrm{e}_{\mathrm{i}}$ の 2 乗平均を

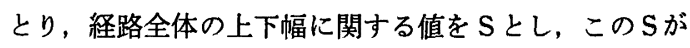
最小となる点を全運動軸点とした. この方法では, 軌跡 の特定の部分にかたよることなく，比較的に全体として 上下幅が小さい点を決定することができる. 


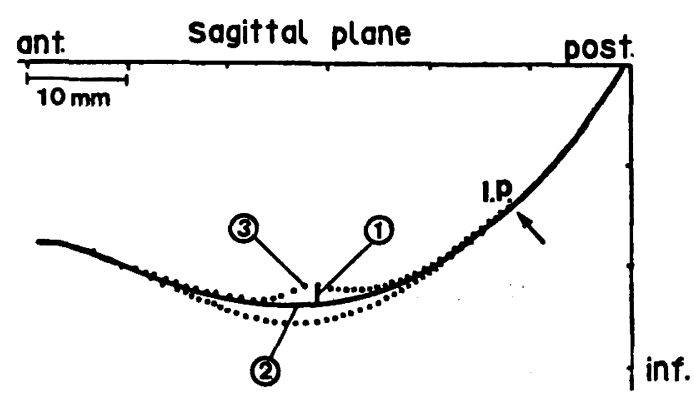

(1) $\mathrm{ei}=\mathrm{Zi}-\mathrm{F}(\mathrm{Xi}):$ residual

(2) $Z=F(X)$ : polynomial approximation

(3) $(X i, Z i)$ : sompled condylar path

$$
(i=1,2, \cdots \cdots \cdots, N)
$$

\section{Polynomial Approximation}

図 21 矢状顆路データへの曲線の当てはめによる上下幅の 定量化

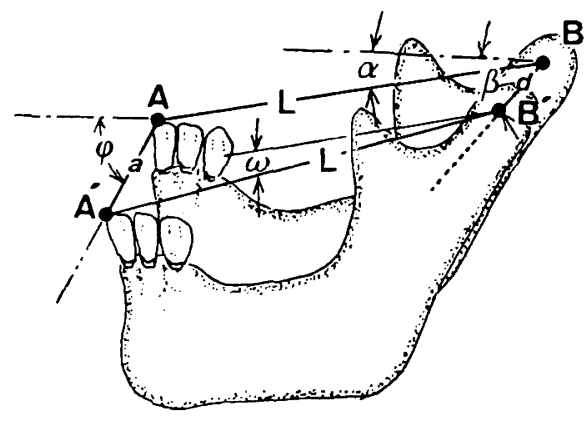

図 22 下額の回転量 $(\omega)$

\section{2. 下顎の回転角について ${ }^{26)}$}

図 22 に示した切歯点 $\mathrm{A}$ と全運動軸点 $\mathrm{B}$ とが $\mathrm{A}^{\prime}, \mathrm{B}^{\prime}$ に移動するとき，下顎は矢状切歯路傾斜度 $\phi$ と矢状顆 路傾斜度 $\beta$ との角度差 $\beta-\phi$ によって回転角 $\omega$ の回転 運動をする. 点 $\mathrm{A}$ と点 $\mathrm{B}$ の運動距離を $\mathrm{a}$ と $\mathrm{d}$ とすれば,

$$
\begin{aligned}
& \omega=\cos ^{-1}\left[1-2^{-1} \mathrm{~L}^{-2}\left\{\mathrm{~d}^{2}-2 \mathrm{ad} \cos (\beta-\phi)+\mathrm{a}^{2}\right\}\right] \\
& \mathrm{d}: \mathrm{IV} . \text { 考察 } 2 \text { の 1) の (1) 式参照) } \cdots \cdots \cdots \text { (2) }
\end{aligned}
$$

と表される. 本研究では切歯点の運動距離を $5 \mathrm{~mm}$ とし たので $\mathrm{a}=5$ とした. ここでは， $\omega$ の性質について詳し く検討する.

1）切歯点 - 全運動軸点間距離 L (矢状面投影) の影

\section{響}

L の影響を調へるために，Lをパラメータとし との関係を図 23 に示す. 本研究での被験者の L の値の

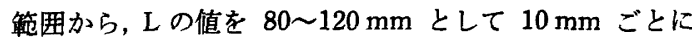
変化させた. 他のパラメータの值は平均值とし $\alpha=14^{\circ}$

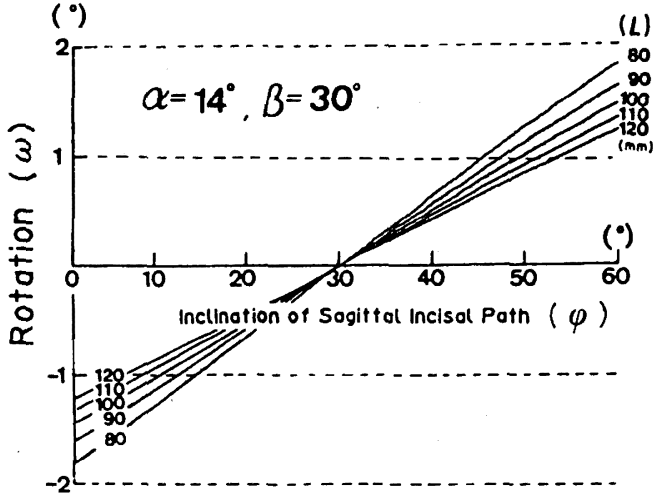

図 23 L (切菌点・全運動軸点間距離) の影響

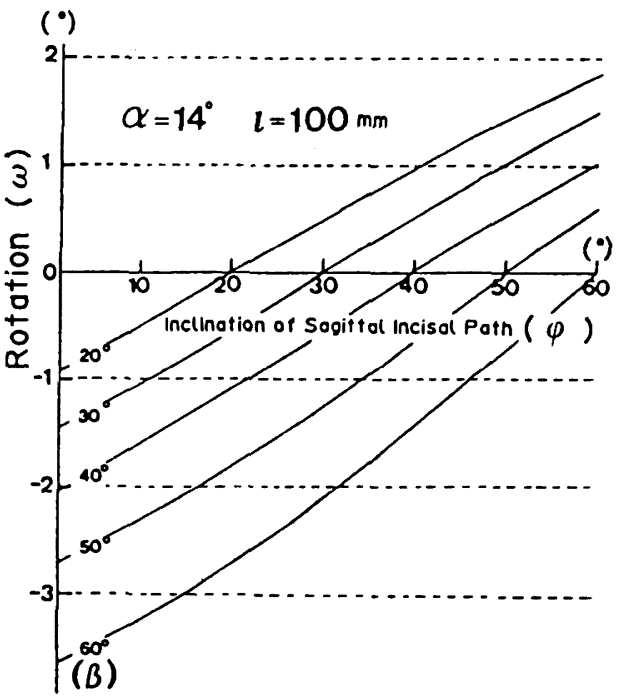

图 $24 \beta$ (矢状顆路傾斜度) の影響

$\beta=30^{\circ}$ とした. これから， $\phi=\beta$ のときに $\omega=0^{\circ}$ となり， $\phi-\beta$ の值が大きく, L の值が小さいときに $\omega$ は最も大 きくなる. しかし，最大でも $\omega<2^{\circ}$ となりきわめて小 さい.

2) $\beta$ の影響

$\beta$ の影響を調べるために, $\beta$ をパラメータとし $\omega$ と $\phi$ との関係を図 24 に示した. $\beta$ は, 本研究での被験者の $\beta$ の值の範囲から, $\beta=20^{\circ} \sim 60^{\circ}$ として $10^{\circ}$ ごとに変化さ せた. このとき $\phi$ の值が増加すると $\omega$ も増加し, 切歯 路傾斜度の約 $10^{\circ}$ の増加に対して $\omega$ が約 $1^{\circ}$ 増加した. $\phi<\beta$ のときに $\omega<0^{\circ}$ となり, さらに, $\beta=60^{\circ}, \phi<10^{\circ}$ のときに $\omega$ は $-3^{\circ}$ を越える. 


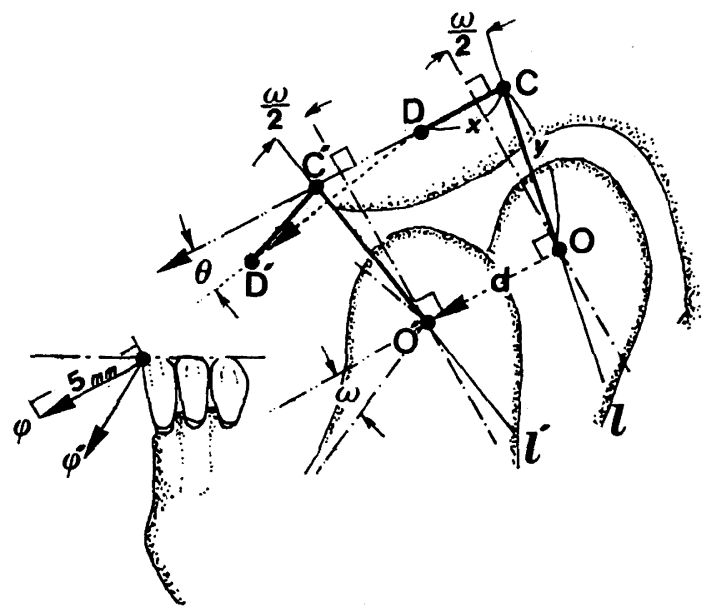

図 25 任意の顆頭点の顆路傾斜度差

\section{3. 任意の顆頭点における顆路傾斜度差 ${ }^{26)}$}

任意の顆頭点における顆路傾斜度差 $\theta$ について説明 する.ここで, 説明を簡単にするために，矢状切歯路傾 斜度 $\phi$ 全運動軸点のなす矢状顆路傾斜度と等しくし て，下顎が回転運動せずに平行移動する場合と，矢状切 歯路傾斜度 $\phi^{\prime}$ を与えて $\omega$ だけ回転運動をする場合の 2 つの前方滑走運動を考え, その時の任意の顆頭点の運動 経路のなす顆路傾斜度差 $\theta$ について調べることにする.

図 25 は任意の顆頭点 D の顆路傾斜度差 $\theta$ についての 説明図である. 点 $\mathrm{O}$ は全運動軸点であり，点 $\mathrm{C}$ は点 $\mathrm{O} の$ 顆路と $\pi / 2+\omega / 2$ だけ角度差をもつ直線 $l$ 上の点で, 点 $\mathrm{O}$ から距離 $\mathrm{y}$ の点である. 点 $\mathrm{D}$ は点 $\mathrm{C}$ を通り点 $\mathrm{O}$ の軌跡 と同じ方向で点 Cから距離 $\mathrm{x}$ の点である.

このとき,

$$
\begin{aligned}
\theta & =\tan ^{-1} \frac{\sin \omega}{1-\cos \omega+x^{-1}(d+2 y \sin \omega / 2)}, \\
& x \neq 0
\end{aligned}
$$

と表される.

1） $\mathrm{y}$ を一定とし，点 $\mathrm{D}$ を顆頭の移動する $\mathrm{CC}^{\prime}$ 方向 に変化させる（点 C を通り $\mathrm{OO}^{\prime}$ に平行な直線上の点列 で点 Cから距離 $\mathrm{x}$ となる点列を考える) と, (3) 式では $\mathrm{x}$ が増加すると $\theta$ も増加し，

$$
\theta \rightarrow \tan ^{-1} \frac{\sin \omega}{1-\cos \omega}=\pi / 2-\omega / 2,(\mathrm{x} \rightarrow \pm \infty)
$$

となり, $\theta$ は $\pi / 2-\omega / 2$ に漸近することがわかる.

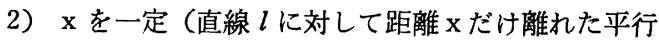
な線上の点列を考える）とし，点 Dの位置を，顆頭の移 動する方向と $\pi / 2+\omega / 2$ の角度をもつ $\mathrm{OC}$ 方向に変化さ せると, (3) 式より, $\mathrm{y}$ が増加すると $\theta$ は減少し,

$$
\theta \rightarrow \tan ^{-1} 0=0,(y \rightarrow \pm \infty)
$$

となり， $\theta$ は 0 に漸近することがわかる. 顆路と $\pi / 2+$ $\omega / 2$ だ角度差をもち点 $\mathrm{O}$ から点 $\mathrm{O}^{\prime}$ 方向に $\mathrm{x}$ の距離の 直線 $l$ に平行な直線 $l^{\prime}$ 上の任意の顆頭点では, この直線

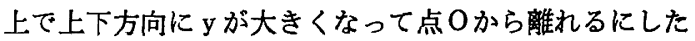
がって, $\theta$ は 0 に渣近し， $\mathrm{x}$ が大きくなって点 $\mathrm{O}$ から $00^{\prime}$ 方向に離れるにしたがって $\theta$ は $\pi / 2-\omega / 2$ に渐近する.

矢状切歯路傾斜度の $0^{\circ} \sim 60^{\circ}$ の変化を与えたときに, 本研究の被験者では, 矢状顆路傾斜度は $14.0^{\circ} \sim 35.9^{\circ}$, 切歯点・全運動軸点間距離は 88〜105 mm であったの で，下效の回転角 $\omega$ は $0^{\circ}<\omega<3^{\circ}$ となり (計算値) 小 さい值となるので, 式 (3) はさらにつぎのように近似す ることができる.

$$
\theta \fallingdotseq \tan ^{-1} \frac{\omega \mathrm{x}}{\mathrm{d}+\omega \mathrm{y}}
$$

ここで $\mathrm{y}=$ const. とすれば, $\theta$ は $\tan ^{-1} \mathrm{x}$ に比例する. さらに, 顆頭周囲での $\mathrm{y}$ の值のあまり大きくない範囲で は $\mathrm{d}>>\omega \mathrm{y}$ であるので, $\theta$ に与える $\mathrm{y}$ の影響はきわめて 少ない，すなわち，直線 $l$ に平行な直線上の任意の顆頭 点のなす $\theta$ の值は, 任意の顆頭点の位置が值線 $l$ 亿平行 な方ではほとんど変化せず, 全運動軸点の移動する方 向ではより大きく変化することがわかる（図 20-a, b).

\section{文献}

1）河野正司：下䫑の矢状面内運動に対応する顆頭 運 動の研 究, 第二報マルチフラッシュ装置による矢状面運動軸の解 析, 補緅誌, $12: 350 \sim 380,1968$.

2）中野雅徳：側方滑走運動の顆路と歯牙路に関寸る研究, 補 緅誌, $19: 461 \sim 479,1975$.

3）塩澤恭郎：下䫛任意点の運動解析，第二報下頡限界運動の 立体解析, 補緅誌, $26: 148 \sim 164,1982$.

4) Clayton, J.A., Kotowits, W.E. and Myers G.E. : Graphic Recordings of Mandibular Movements. Research Criteria, J. Pros. Dent., $25: 287 \sim 298,1971$.

5）鶴見祐三：咬合非誘導と咬合誘導における顆路の変化に関 寸る研究, 歯科学報, $75: 1401 \sim 1434,1975$.

6）栗山 䐝：歯牙指導要素が平衡側顆路に及ぼ寸影響につい て, 補緅誌, $23: 126 \sim 147,1978$.

7）塩澤恭郎, 林 豊彦, 加藤一誠, 野村修一, 石岡 靖：歯 牙要素の実験的変化による顆頭運動への影響，下顯運動機 能と $\mathrm{EMG}$ 論文集, $51 \sim 57,1982$.

8）塩澤恭郎, 林 豊彦, 野村修一, 他 : 下顎任意点の運動解 析, 第一報測定システム, 補緅誌, $25: 499 \sim 507,1981$.

9）林 豊彦, 塩澤恭郎, 加藤一誠, 野村修一, 石岡 靖: 下 顎運動の 3 次元測定解析システムの開発, 信技報, MBE 82-32: 55 62, 1982. 
10) Beck, H.O. : A clinical evaluation of the arcon concept of articulation, J. Pros. Dent., $9: 409 \sim 421$, 1959.

11）林 豊彦, 加藤一誠, 石岡 靖: 非線形最適化アルゴリズ ムによる全運動軸の自動探索法について, 下筫運動機能と EMG 論文集, 1985.

12）長谷川成男, 藍稳, 河野正司, 坂東永一, 真柳昭紘, 野村孝太郎, 福島俊士, 川口豊造 : 下䂓限界運動における 全運動軸の立体的測定, 補緅誌, $19: 434 \sim 443,1975$.

13） 白井良明, 伊藤 浩, 伊藤 孝, 鶴見祐三, 斉藤文明, 奥 野和志, 高宮紳一郎, 腰原 好 : 顆頭点の設定位㯰と咬合 器の再現性に関する研究, 第一報平均的顆頭点, 蝶番軸, 全運動軸の位置的関係, 補緅誌, $25: 499 \sim 507,1981$.

14）荒野 実: 矢状面内下额限界運動の解析, 歯科学報, 77 : 967 1009, 1977.

15）林 崇民：䪽連動に関する歯科矯正学的研究，側貌セファ ログラム上における二次元的解析，歯科学報， $79: 423$ $459,1979$.

16）坂東永一, 他：写真撮影法による下䫟運動測定法, 補綴 誌, $23: 677 \sim 690,1979$.

17) Aull, A.E. : Condylar Determinants of occlusal patterns, J. Pros. Dent., 15 : 826 846, 1965.

18) McCollum, B.B. and Stuart, C. E. : A research report, Calif, Scientic Pres, 9 123, 1955.

19) McCollum, B.B., Fundamentals involved in prescribing restrative dental remedies, Den. Items of Int., $61: 522 \sim 535,641 \sim 648,724 \sim 736,852 \sim 863,942 \sim 950$, 1939.

20) Isaacson, D. : A clinical study of the condyle path,
J. Pros. Dent., 9 : 927 935, 1959.

21) LePera, F. : Determination of the Hinge-axis, J. Pros. Dent., $14: 651 \sim 660,1964$.

22) Shanahan, T.E.J. and Leff, A. : Mndibular and Articular movements, Part VII. Concepts of lateral movements and condyle paths, J. Pros. Dent., $14: 279$ $\sim 289,1964$.

23) Weinberg, L.A.: The transverse hinge axis: real or imaginary, J. Pros. Dent., 9 : 775 787, 1959.

24）石原寿郎, 他：Hinge axis, 下䫑の蝶番運動軸について, 每科時報, 16, 1962., 17, 1963.

25) Vaughan, H.C. : Need for changes in concepts relating to the temporomandibular joint and the mandibular articulation, J. Pros. Dent., $17: 406 \sim 417$, 1967.

26）加藤一誠, 白木誠一, 根津正美, 林 豊彦, 塩澤恭郎, 野 村修一, 石岡 靖 : 矢状切歯路傾斜度の変化に対寸る顆路 傾斜度の再現性について, 下顎運動機能と EMG 論文集, $55 \sim 62,1985$.

27）河野正司, 加藤 均, 中野雅徳 : 顎口腔機能系の機能にお けるアンテリオール・ガイダンスの働き, 下䫑運動機能と EMG 論文集, $1 \sim 5,1985$.

28）中野雅徳，久保吉臀，坂東永一：顎機能異常を若き起こす 歯の Guide について, 下顎運動機能と EMG 論文集, $7 \sim 12,1985$.

29) LePera, F.: Understanding graphic records of mandibular movements, J. Pros. Dent., $18: 417 \sim 424$, 1967. 